\title{
La escasa persecución del delito de falso testimonio: una constatación paradójica
}

\section{The low prosecution of the crime of perjury and false declarations before court -Confirming a paradox}

\author{
Pilar Rey \\ Profesora Ayudante de Derecho penal \\ Universitat Internacional de Catalunya \\ mprey@uic.es \\ Dr. Guillermo Benlloch \\ Magistrado y Profesor Asociado de Derecho penal \\ Universitat Internacional de Catalunya \\ gbenlloch@uic.es \\ Dr. José R. Agustina \\ Catedrático acr. de Derecho penal \\ Universitat Internacional de Catalunya \\ jragustina@uic.es
}

Resumen: El delito de falso testimonio ha estado presente y sigue estándolo en los ordenamientos jurídicos de todo tiempo y lugar. Podría decirse que allá donde existe un proceso judicial mínimamente formalizado se ha advertido la necesidad de dotarlo de protección a través de la incriminación del falso testimonio.

Ahora bien, esta universal tipificación del delito de falso testimonio -que parece evidenciar la importante función de tutela que le atribuyen los distintos legisladorescontrasta paradójicamente con los niveles relativamente escasos de persecución de este delito que se constatan en la práctica de los tribunales.

Para evidenciar y tratar de dimensionar este fenómeno -la escasa persecución de este delito pese a no ser infrecuente su comisión-, acudiremos al análisis de los datos estadísticos disponibles, así como a las fuentes doctrinales y a los pronunciamientos de los tribunales. A la luz del análisis efectuado se sugieren nuevas líneas de investigación y algunas cuestiones que requerirían una reformulación de la política criminal en relación a la persecución del falso testimonio.

Palabras clave: delito de falso testimonio, escasa persecución, perjurio, derecho penal comparado.

Abstract: The crime of false testimony has been and continues to be a figure of great relevance in the legal systems of all times. It could be said that whenever there is a minimally formalized process, there is a need to protect it through the incrimination of false testimony. Thus, in the different legal cultures, legislators from all over the world 
continue to punish the untruthful witness in order to preserve the proper administration of justice.

However, as a paradox, despite the universal typification of the crime of false testimony -which seems to demonstrate the important role that the different legislators confer to this crime - in practice, there is a relatively low rate of prosecution for such crime.

In order to measure the dimension of this phenomenon and demonstrate the low prosecution of this crime as well as the high level of dark figures, this paper uses the available statistical data, the doctrinal sources and the case-law. Finally, several relevant issues emerged from the analysis of the different implications and explanatory hypotheses concerning this paradoxical ascertainment. All these issues suggest the need to adopt new lines of research in an area of an undoubted significance for any justice system.

Keywords: false testimony, scant prosecution, perjury, comparative criminal law.

\section{Introducción: relevancia y función del delito de falso testimonio en el sistema de justicia. La incriminación del falso testimonio: una constante histórica, una tendencia universal y algunas sospechas preliminares sobre su baja persecución}

Pocas conductas han sido objeto de una incriminación penal más estable y universal que el falso testimonio. Una simple observación histórica nos revela que allá donde ha existido un proceso judicial mínimamente formalizado, allí se ha previsto también un castigo penal para los testigos mendaces y esto vale tanto para los sistemas judiciales más primitivos como para los tribunales internacionales de más reciente creación; y lo mismo para sistemas jurídicos teocráticos o de raíz religiosa, como para sistemas jurídicos seculares o de naturaleza aconfesional ${ }^{1}$.

Hoy como ayer sigue atribuyéndose al delito de falso testimonio un importante papel: es el medio principal con que el legislador pretende reforzar el deber de veracidad del testigo, ayudando a que el cumplimiento de este deber prevalezca frente a la posible tentación de faltar a la verdad ${ }^{2}$. En este sentido, como ya señalara Bentham en su

\footnotetext{
${ }^{1}$ Son muchos los autores que han abordado el estudio de la importante tradición histórica que rodea al delito de falso testimonio y el perjurio. Cfr. MILLÁN GARRIDO, Antonio, "El delito de falso

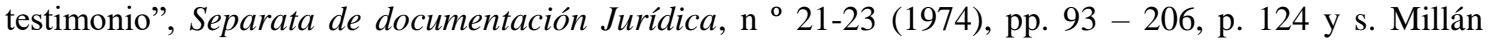
Garrido sostiene que todos los sistemas jurídicos, con independencia de la fórmula concreta, vienen a castigar la alteración de la verdad, y que el hecho de que las legislaciones tipifiquen la conducta del testigo mendaz como perjurio, o como falso testimonio, viene a ser reflejo del mayor o menor proceso de secularización del sistema legislativo, sin que suponga en la actualidad una diferenciación, por lo general, de gran trascendencia práctica. Cfr. TORÍO LÓPEZ, Ángel, "Introducción al falso testimonio", Revista de Derecho Procesal, $\mathrm{n}^{\circ} 1$ (1965), pp. 1 - 25, p. 3. Respecto a la trascendencia histórica de esta figura, véase también DOMÍNGUEZ IZQUIERDO, Eva M., El falso testimonio de testigos, peritos e intérpretes, Madrid: Editoriales de Derecho Reunidas, 2002, pp. 43 y s. MAGALDI PATERNOSTRO, María José, El falso testimonio en el sistema penal español, Barcelona: Promociones Publicaciones Universitarias, 1987, p. 114 y s.

${ }^{2}$ KINDHÄUSER, Urs, "Estructura y legitimación de los delitos de peligro del Derecho penal", Trad.: PASTOR, Nuria, InDret, n ${ }^{\circ} 1$ (2009) , pp. 1 - 19, p. 19 en: http://www.indret.com/pdf/600.pdf [visitado el 17.1.2017]. Sostiene el autor que en la medida que, desde la perspectiva práctica, para adquirir un
} 
Tratado de las pruebas judiciales, "de todas las garantías que contribuyen a obtener la verdad en el testimonio, la más poderosa es la pena legal"3.

El delito de falso testimonio viene, pues, a cumplir una importante función sistémica en el marco de todo proceso jurisdiccional. Y esta función primordial explica que se trate de un tipo penal vivo que no se ha limitado a perdurar en los distintos ordenamientos jurídicos, sino que ha ido evolucionando y adaptándose a la realidad sociocultural y a las necesidades jurisdiccionales en distintas épocas ${ }^{4}$. Y esta importancia es la que explica igualmente que no solo a nivel nacional, sino también en sistemas jurisdiccionales supranacionales, como son los del ámbito comunitario e internacional, se acuda a la figura del delito de falso testimonio ${ }^{5}$. E incluso más allá: son muchas y

conocimiento correcto de los hechos es relevante la prueba de testigos y de peritos, en esa medida, los falsos testimonios también son especialmente idóneos para originar fallos incorrectos.

${ }^{3}$ BENTHAM, Jeremy, Tratado de las pruebas judiciales, tomo I, Trad.: GOMEZ DE CASTRO, José, Madrid: Imprenta de Tomás Jordán, 1835, pp. 95 - 96.

${ }^{4}$ En este sentido, Cfr. ALEJANDRE GARCÍA, Juan Antonio, "El delito de falsedad testimonial en el Derecho histórico español", Historia, instituciones, documentos, no 3 (1975), pp. 9 - 140. Alejandre describe cómo el delito de falso testimonio ha ido evolucionando a la vez que evolucionaba la sociedad, tratando de dar respuesta a las necesidades de una sociedad, y un proceso, cada vez más complejo. También es de destacar, respecto a la evolución del delito de falso testimonio, con una visión más universal que el anterior, MILLÁN GARRIDO, "El delito de falso", cit. nota $\mathrm{n}^{\mathrm{o}} 1$. Y en derecho comparado Cfr. CASTILLO GONZALEZ, Francisco, El delito de falso testimonio, San José de Costa Rica: Juricentro, 1982, pp. 18 a 41; LEVENE, Ricardo, El delito de falso testimonio, Buenos Aires: Ediciones Depalma, 1975; AMIGO ROMAN, Carlos, "El falso testimonio: aspectos jurídicos procesales y derecho comparado", Revista vasca de derecho procesal y arbitraje, no 2 (2010), pp. 279 - 314, p. 279 y s.

${ }^{5}$ En el ámbito del derecho internacional encontramos con que también se recurre a la figura del delito de falso testimonio, acudiéndose a este tipo delictivo en las normas que regulan los sistemas jurisdiccionales supranacionales de reciente creación, tanto en el ámbito europeo, como en el ámbito internacional. Así, en el ámbito comunitario, encontramos que se acude al delito de falso testimonio en el art. 76 del Reglamento de 21 de mayo 2014 que regula el procedimiento del Tribunal de la Función Pública de la Unión Europea, el art. 98 del Reglamento de 4 de marzo 2015 en el que se regula el procedimiento del Tribunal General de la Unión Europea, y el art. 6 del Reglamento adicional de 17 de diciembre 2013 del Tribunal de Justicia de la Unión Europea. En el ámbito de las jurisdicciones internacionales, encontramos con que también las legislaciones por las que se regulan los procesos de los Tribunales Internacionales han recurrido al delito de falso testimonio para proteger la función jurisdiccional. Así, por ejemplo, ya en el propio Estatuto de Roma de 17 de julio de 2008, por el que se constituye la Corte Penal Internacional, en sus artículos 69 y 70 se recoge expresamente la obligación de decir verdad que tienen los testigos, y la propia Corte se declara competente para conocer de los delitos contra la administración de justicia que se cometan en el seno de dicha jurisdicción. En sistemas jurisdiccionales de nueva creación -como los Tribunales que se crearon para el enjuiciamiento de los crímenes de Rwanda y Yugoslavia) se acudió a la incriminación del falso testimonio en Reglas 91 (A) y 91 (G) de las Reglas de Procedimiento y Prueba de 11 de febrero de 1994 establecidas en base a los Artículos 15 y 14 del Estatuto del Tribunal Penal Internacional para la antigua Yugoslavia, Resolución del Consejo de Seguridad de Naciones Unidas 827 de 25 de mayo de 1993, y del Estatuto del Tribunal Internacional para Rwanda, aprobado por la resolución 955 del Consejo de Seguridad de las Naciones Unidas el 8 de noviembre de 1994. A este respecto, cfr. DEL CARPIO, Juana, "Las víctimas como testigos en el Derecho Penal Internacional. Especial referencia a los Tribunales ad hoc", Política criminal, Vol 8, no 15 (2013), pp. 128 - 169, en: http://www.politicacriminal.cl/Vol_08/n_15/Vol8N15A4.pdf [visitado el 17.1.2017], p. 140 y s. y WALD, Patricia M., "Dealing with witnesses in War Crime Trials: Lessons form the yugoslav Tribunal" Yale Human Rights and Development Law Journal, vol. 5 (2002), pp. 217 - 239, p. 227 y s. En los tribunales de Rwanda y Yugoslavia, si bien la prueba testifical resultó ser un medio probatorio esencial también conllevaba, por la naturaleza y crueldad de los hechos enjuiciados, unas problemáticas importantes en cuanto a su falibilidad. Una de estas dificultades es que existía un claro riesgo de que, pese a las advertencias y obligaciones legales, la víctima pudiera prestar un testimonio falso influenciado por el odio, el resentimiento, la sed de venganza, el miedo, el dinero, etc. (cfr. ZAHAR, Alexander, "The 
diversas las voces que en el ámbito del proceso arbitral vienen reclamando que el delito de falso testimonio amplíe su ámbito de protección -abarcando también el falso testimonio vertido en el seno de un proceso arbitral- para con ello reforzar los deberes de veracidad de los testigos que deponen en el seno de dichos procesos ${ }^{6}$.

Ciertamente, son muchas las normas de nuestro derecho histórico que reflejan la preocupación legislativa a la hora de proteger penalmente el proceso judicial frente al peligro que entraña el falso testimonio para la recta administración de justicia ${ }^{7}$. Asimismo, en la evolución del ordenamiento jurídico español se observa cómo esta figura delictiva ha sido objeto de una renovación y adecuación normativa ${ }^{8}$, tendencia que se verifica en otros ordenamientos?

Resulta especialmente significativo que, desde que en 1822 se aprobara el primer Código Penal español, en los ocho textos penales posteriores $-\mathrm{y}$ en sucesivas y diversas reformas- se han introducido cambios en la configuración de los delitos de falso testimonio, siendo muchas de esas modificaciones sobre cuestiones de trascendencia en cuanto a la definición y alcance de la conducta descrita por el tipo penal ${ }^{10}$. Todo ello

problem of false testimony at the International Criminal Tribunal for Rwanda", en: KLIP, André; GÖRAN, Sluiter (Eds), Annotated leading cases of international criminal tribunals, Vol. 25: International Criminal Tribunal for Rwanda, 2006-2007, Intersentia, 2010, pp. 509 - 522).

${ }^{6}$ Cfr. LÓPEZ ANDINO, Juan Antonio, "Sobre el delito de falso testimonio en el marco de un procedimiento arbitral ", Anuario de justicia alternativa: derecho arbitral, no 7 (2006), pp. 107 - 127. En el mismo sentido que recoge este autor, es de destacar que el Tribunal Arbitral de Barcelona, en el año 2014, hizo una propuesta de enmienda de modificación del artículo 458 del Código Penal para que incluyera, además del falso testimonio en causa judicial, el realizado en un procedimiento arbitral:

http://www.diariojuridico.com/el-tribunal-arbitral-de-barcelona-propone-tipificar-el-falso-testimonioarbitral-como-delito/ [consultado el 21/07/2017].

Asimismo, cfr. ROTH, Marianne, "Consequences and Prevention of False Evidence Under the English Arbitration Act 1996: A Comparative Perspective", Arbitration International, Vol. 13, n ${ }^{\circ} 4$ (1997), pp. 391 - 397, p. 394. Con la legislación suiza como ejemplo, sostiene la autora que las sanciones civiles y penales por falsos testimonios en el arbitraje favorecen la percepción de honestidad y justicia en el proceso arbitral, y a largo plazo fomentan el arbitraje como un sistema de solución de controversias.

Cfr. ALEJANDRE GARCÍA, Juan Antonio, Falsedad documental y falsedad testimonial. Estudio histórico-jurídico de dos tipos delictivos, Madrid: Dykinson, 2012.

${ }^{8}$ Cfr. ALEJANDRE, "El delito de falsedad testimonial", cit. nota n 4 , RODRÍGUEZ ENNES, Luis, "La prueba testifical y algunas circunstancias modificativas de la responsabilidad penal en Roma y en el antiguo régimen", en CASTÁN PÉREZ-GÓMEZ, Santiago, et al., Homenaje al Profesor Armando Torrent, Madrid: Dykinson, 2016, pp. 829 - 944.

${ }^{9}$ En este sentido LEVENE, El delito de falso, cit. nota $\mathrm{n}^{\circ} 4$, p. 159 y ss., en una publicación datada en 1975 realizó un compendio de las distintas tipificaciones del falso testimonio en diversos ordenamientos jurídicos. Si se comparan las disposiciones recogidas en dicha obra con las que recogen dichos ordenamientos jurídicos en la actualidad, podemos apreciar cómo ha ido evolucionando el delito de falso testimonio no solo a efectos penológicos, sino en muchos casos también en aspectos tan esenciales como la configuración de los tipos dedicados a regular la conducta.

${ }^{10}$ Cfr. FARALDO CABANA, Patricia; CATALINA BENAVENTE, María Ángeles; CLEMENTE DÍAZ, Miguel, El falso testimonio de testigos, peritos e intérpretes, Valencia: Tirant lo Blanch, 2016, pp. 123137. Los delitos de falso testimonio ya se recogieron en el primer Código penal español, el de 1822, y en todos los códigos posteriores no solo permaneció recogida esta figura, sino que además en todos ellos -en los Códigos penales de 1848, de 1850, de 1870, de 1928, de 1932, de 1944, de 1973- se fueron introduciendo importantes modificaciones en su configuración, que afectaban a aspectos tan esenciales como es la definición del hecho punible, a la pena a imponer, a los sujetos activos, a las conductas relacionadas con el falso testimonio etc. También el Código Penal de 1995, primer Código Penal que se aprobó tras la promulgación de la Constitución Española de 1978 -vigente en la actualidad- recogió el delito de falso testimonio en su artículo 458 y siguientes del Código Penal, y ha sido posteriormente 
parece indicar que la lucha contra la mendacidad en el proceso es un aspecto al que el legislador ha conferido una especial relevancia desde un punto de vista políticocriminal.

Desde un punto de vista comparado, las especificidades de cada uno de los sistemas jurídicos han dado lugar a que existan distintos modelos de tipificación del delito. No obstante, las diferencias advertibles en los distintos ordenamientos son de matiz ${ }^{11}$ : en algunos, el fundamento de la punición parece situarse más bien en la vulneración del juramento o promesa de decir verdad en juicio -perjurio-; en otros, en la infracción del deber de ser veraz al prestar declaración ante un tribunal -falso testimonio en sentido estricto-, castigándose dichas conductas con unas penas más o menos severas ${ }^{12}$. Sin embargo, con independencia de la fórmula concreta adoptada, todos los modelos de incriminación del falso testimonio comparten un mismo objetivo: reducir la falibilidad de la administración de justicia a través de la persecución y punición penal del falso testimonio $^{13}$, de modo que se eviten las injusticias materiales que puedan derivarse de una fijación inexacta de los presupuestos histórico-fácticos de las resoluciones judiciales $^{14}$.

Los aspectos más relevantes contenidos en distintas legislaciones se pueden apreciar en la siguiente tabla: ${ }^{15}$

modificado tanto en la reforma del año 2003 como en la del año 2015. En la actualidad, dentro del Título XX del Código Penal Español de 1995 (en adelante CP), dedicado en exclusiva a los delitos contra la administración de justicia, el legislador ha descrito las conductas relacionadas con el falso testimonio dedicándoles el Capítulo VI. En este capítulo vemos que, además de definir el delito de falso testimonio en el tipo básico del art. $458 \mathrm{CP}$, el legislador completa el elenco de conductas relacionadas con el testimonio inveraz, y que son: un subtipo agravado para los peritos e intérpretes que falten a su deber de veracidad en el art. $459 \mathrm{CP}$; un subtipo atenuado, en el art. $460 \mathrm{CP}$, por el que se castiga las reticencias o inexactitudes en las que pueda incurrir el testigo o perito en su declaración; en el art. $461 \mathrm{CP}$ se tipifica también la presentación de testigos falsos y, por último, en su art. 462 CP establece la retractación como excusa absolutoria o, en su caso, como atenuante específica.

${ }^{11}$ Cfr. ADIP, Amado, Prueba de testigos y falso testimonio, Buenos Aires: Ediciones Depalma, 1977, p. 1 - 4, AMIGO ROMAN, "El falso testimonio", cit. nota no 4, pp. 279 - 314 El autor hace un estudio de derecho comparado acerca de los diferentes antecedentes históricos del falso testimonio, en las distintas culturas, y destaca que ya en los derechos más primitivos como el derecho babilónico -Código Hammurabi S. XXXIII a.C.-, en derecho hebrero -a través del Decálogo y el Talmud-, en el derecho hindú -en el Código de Manú-, en el derecho griego, en el derecho romano, en el derecho germánico, en el derecho canónico, entre otros, ya se preveían medidas procesales con los que -junto con el prever un castigo para la conducta de quien cometa falsedad al testificar-, se procuraba la fiabilidad de este medio probatorio. Cfr. DOMÍNGUEZ IZQUIERDO, El falso testimonio de testigos, cit. nota nº 1, p. 47.

${ }^{12}$ Sobre el perjurio y testimonio en derecho comparado, MILLÁN GARRIDO, "El delito de falso", cit. nota $\mathrm{n}^{\mathrm{o}} 1$, p. $125-130$

13 HERNÁNDEZ GUIJARRO, José Julián, "Naturaleza del delito de falso testimonio", Anuario de derecho penal y ciencias penales, vol. 20, nº 1 (1967), pp. 333 - 350, p. 333 y s.

${ }^{14}$ BENLLOCH, Guillermo, "Delitos contra la Administración de Justicia", en: SILVA SÁNCHEZ, Jesús María (Dir.); RAGUÉS, Ramón (Coord.), Lecciones de Derecho penal. Parte especial, $4^{\mathrm{a}}$ ed., Barcelona: Atelier Libros Jurídicos, 2015, pp. 387 - 414, p. 401.

${ }^{15} \mathrm{La}$ presente tabla se ha realizado, en su mayoría, consultando los códigos penales de los países relacionados a través de las versiones que aparecen publicadas en la base de datos WIPO Lex. Se trata de una base mundial de datos que brinda acceso a información jurídica sobre propiedad intelectual, incluyendo en muchas ocasiones los preceptos penales relativos al falso testimonio. En los casos que no estaba el texto penal completo, o no estaba disponible en español, inglés o francés, mediante la referencia a la norma hemos obtenido los datos necesarios para buscar el texto penal vigente en la actualidad, a través de internet, siempre en lengua inglesa o española. WIPO Lex es una base de datos gestionada por 


\section{Tabla 1: La tipificación de la conducta de falso testimonio en derecho comparado}

\begin{tabular}{|c|c|c|c|c|c|}
\hline País & $\begin{array}{l}\text { CP vigente } \\
\text { (año de } \\
\text { publicación) }\end{array}$ & Artículos & $\begin{array}{l}\text { Pena del tipo básico del delito de } \\
\text { falso testimonio }\end{array}$ & $\begin{array}{l}\text { ¿Se castiga } \\
\text { el perjurio? }\end{array}$ & Características especiales \\
\hline Alemania & 1975 & $\begin{array}{l}\$ 153 \text { al } \\
\$ 163\end{array}$ & $\begin{array}{l}\text { Falso testimonio de } 3 \text { meses a } 5 \\
\text { años. } \\
\text { Perjurio: Grave: prisión mínima de } \\
1 \text { año } \\
\text { menos grave: prisión de } 6 \text { meses a } \\
5 \text { años. }\end{array}$ & Sí & $\begin{array}{l}\text { Prevé la retractación como } \\
\text { atenuante o eximente. } \\
\text { Para la modalidad grave establece } \\
\text { una pena mínima pero no una } \\
\text { pena máxima. }\end{array}$ \\
\hline Bélgica & 1867 & $\begin{array}{l}\text { Art. } 215 \text { al } \\
\text { art. } 226\end{array}$ & $\begin{array}{l}\text { En causa penal: reclusión 5-10 } \\
\text { años } \\
\text { en causa civil: reclusión de } \\
\text { 10meses } \\
\text { a } 3 \text { años. }\end{array}$ & No & No prevé la retractación. \\
\hline Bolivia & 1972 & $\begin{array}{l}\text { Art. } 169 \text { al } \\
\text { art. } 170\end{array}$ & $\begin{array}{l}\text { Reclusión de } 1 \text { a } 15 \text { meses. } \\
\text { en causa criminal en perjuicio del } \\
\text { inculpado privación de libertad de } \\
1 \text { a } 3 \text { años. }\end{array}$ & No & $\begin{array}{l}\text { No prevé retractación. Incluye } \\
\text { procedimientos administrativos. } \\
\text { Establece como agravante si ha } \\
\text { sido mediante soborno. }\end{array}$ \\
\hline Brasil & 1940 & $\begin{array}{l}\text { Art. } 342 \text { al } \\
\text { art. } 343\end{array}$ & Reclusión de 1 a 3 años y multa. & No & $\begin{array}{l}\text { Incluye el falso testimonio en } \\
\text { procedimientos arbitrales de } \\
\text { forma expresa. }\end{array}$ \\
\hline Bulgaria & 1968 & $\begin{array}{l}\text { Art. } 290 \text { al } \\
\text { art. } 293\end{array}$ & $\begin{array}{l}\text { Prisión de } 2 \text { a } 5 \text { años } \\
\text { Modalidad atenuada (sin } \\
\text { juramento) hasta } 3 \text { años de prisión. }\end{array}$ & Sí & $\begin{array}{l}\text { Prevé la retractación como } \\
\text { atenuante. }\end{array}$ \\
\hline Chile & 1874 & $\begin{array}{l}\text { Art. } 206 \text { al } \\
\text { art. } 210\end{array}$ & $\begin{array}{l}\text { Ante un tribunal: presidio menor } \\
\text { (grado min y medio } 61 \text { a } 540 \text { días) } \\
\text { y multa. } \\
\text { En causa civil: presidio menor } \\
\text { (grado medio } 541 \text { días a } 3 \text { años) y } \\
\text { multa } \\
\text { en causa penal: presidio menor } \\
\text { (grados medio y máximo) y multa. }\end{array}$ & No & $\begin{array}{l}\text { Agravado si es contra reo (de } 3 \\
\text { años y } 1 \text { día a } 5 \text { años) } \\
\text { Contempla la retractación } \\
\text { atenuada y alude al perjuro en } \\
\text { causa no contenciosa. }\end{array}$ \\
\hline China & 1979 & $\begin{array}{l}\text { Art. } 305 \text { al } \\
\text { art. } 307\end{array}$ & $\begin{array}{l}\text { En causa criminal pena de prisión } \\
\text { de hasta } 3 \text { años. } \\
\text { En causa criminal agravada de } 3 \\
\text { años a } 7 \text { años. }\end{array}$ & No & $\begin{array}{l}\text { Parece limitarse al falso } \\
\text { testimonio en causa criminal. La } \\
\text { agravación de la pena será en } \\
\text { función de la gravedad de las } \\
\text { circunstancias en que se cometió } \\
\text { el delito. }\end{array}$ \\
\hline Colombia & 2000 & $\begin{array}{l}\text { Art. } 442 \text { al } \\
\text { art. } 444 \mathrm{~A}\end{array}$ & $\begin{array}{l}\text { Pena de } 6 \text { a } 12 \text { años de prisión. } \\
\text { Para el que soborna al testigo con } \\
\text { pena de } 4 \text { a } 8 \text { años (y multa, } \\
\text { superior si es en causa criminal). }\end{array}$ & No & $\begin{array}{l}\text { La retractación se contempla } \\
\text { como atenuante. } \\
\text { No diferencia el falso testimonio } \\
\text { en causa civil y penal. } \\
\text { En el año } 2004 \text { se modificó } \\
\text { incrementando sensiblemente las } \\
\text { penas. }\end{array}$ \\
\hline Corea & 1953 & $\begin{array}{l}\text { Art. } 152 \text { al } \\
\text { art. } 154\end{array}$ & $\begin{array}{l}\text { Pena de hasta } 5 \text { años o multa } \\
\text { En causa criminal pena de hasta } 10 \\
\text { años. }\end{array}$ & Sí & $\begin{array}{l}\text { Retractación como atenuante o } \\
\text { eximente. }\end{array}$ \\
\hline
\end{tabular}

la OMPI (Organización Mundial de la Propiedad Intelectual), organismo especializado en la Propiedad intelectual y que depende de las Naciones Unidas. La dirección de la página de consulta es la siguiente: http://www.wipo.int/wipolex/es/about.html. Se ha recogido una muestra de países que ejemplifican las principales culturas jurídicas que coexisten en la actualidad: países de Europa continental (incluyendo del norte y del sur), países de tradición anglosajona, países de Europa del este, con influencia soviética, países de Latinoamérica, países islámicos y países asiáticos. Asimismo, se ha referenciado los que todavía incluyen la figura del perjurio como forma de tipificación de la conducta del testigo inveraz (ya sea en exclusiva o junto con el delito de falso testimonio). A este respecto cfr. MILLÁN GARRIDO, "El delito de falso", cit. nota ${ }^{\circ} 1$, p. 25 . El autor apunta a que en derecho comparado no puede hablarse de una bipartición estanca entre los sistemas que castigan el perjurio y los que castigan el falso testimonio. Según Millán Garrido, las distintas legislaciones (las que castigan solo el perjurio, que castigan el falso testimonio, o que siguen un sistema mixto) son reflejo de diferentes estadios del proceso de secularización de estos delitos. En el mismo sentido, TORÍO, “Introducción”, cit. nota n 1 . 


\begin{tabular}{|c|c|c|c|c|c|}
\hline Cuba & 1987 & $\begin{array}{l}\text { Art. } 155 \text { al } \\
\text { art. } 157\end{array}$ & $\begin{array}{l}\text { Pena de prisión de } 1 \text { a } 3 \text { años o } \\
\text { multa } \\
\text { En causa penal y con perjuicio } \\
\text { grave pena de prisión de } 3 \text { a } 8 \\
\text { años. }\end{array}$ & Sí & $\begin{array}{l}\text { Prevé la retractación como } \\
\text { eximente si el falso testimonio no } \\
\text { ha llegado a tener efectos. }\end{array}$ \\
\hline Costa Rica & 1970 & $\begin{array}{l}\text { Art. } 316 \text { al } \\
\text { art. } 318\end{array}$ & $\begin{array}{l}\text { En general prisión de } 1 \text { a } 5 \text { años } \\
\text { En causa criminal contra reo pena } \\
\text { de prisión de } 2 \text { a } 8 \text { años } \\
\text { Perjurio: pena de prisión de } 3 \\
\text { meses a } 2 \text { años. }\end{array}$ & Sí & $\begin{array}{l}\text { Agravante por soborno. } \\
\text { No tipifica el perjurio como } \\
\text { delito contra la Administración } \\
\text { de Justicia, sino al que miente } \\
\text { bajo juramento impuesto por ley, } \\
\text { en relación a hechos propios. }\end{array}$ \\
\hline Dinamarca & 2016 & $\begin{array}{l}\$ 158 \text { al } \\
\$ 163\end{array}$ & Pena de prisión hasta 4 años. & Sí & $\begin{array}{l}\text { Se incluye como modalidad } \\
\text { atenuada el delito de falso } \\
\text { testimonio ante autoridad o } \\
\text { asunto público. }\end{array}$ \\
\hline Ecuador & 2014 & Art. 270 & $\begin{array}{l}\text { Perjurio pena de prisión de } 3 \text { a } 5 \\
\text { años, en causa penal pena de } \\
\text { prisión de } 7 \text { a } 10 \text { años. } \\
\text { Falso testimonio (sin juramento): } \\
\text { pena de prisión de } 1 \text { a } 3 \text { años. En } \\
\text { causa penal de } 5 \text { a } 7 \text { años de } \\
\text { prisión. }\end{array}$ & Sí & $\begin{array}{l}\text { Extiende la protección a las } \\
\text { declaraciones patrimoniales } \\
\text { juradas ante notario. }\end{array}$ \\
\hline El Salvador & 1973 & Art. 305 & Pena de prisión de 2 a 5 años. & No & $\begin{array}{l}\text { Excusa absolutoria si lo presta } \\
\text { cónyuge, ascendiente o } \\
\text { descendente. }\end{array}$ \\
\hline España & 1995 & $\begin{array}{l}\text { Art. } 458 \text { al } \\
\text { art. } 462\end{array}$ & $\begin{array}{l}\text { Pena de prisión de } 6 \text { mes a } 2 \text { años } \\
\text { y multa. } \\
\text { En proceso penal contra reo pena } \\
\text { de prisión de } 1 \text { a } 3 \text { años y multa. }\end{array}$ & No & $\begin{array}{l}\text { Prevé un subtipo atenuado para } \\
\text { las reticencias e inexactitudes y } \\
\text { agravado para los peritos e } \\
\text { intérpretes. } \\
\text { Recoge la retractación como } \\
\text { excusa absolutoria. }\end{array}$ \\
\hline $\begin{array}{l}\text { Estados } \\
\text { Unidos (ley } \\
\text { federal) }\end{array}$ & 1948 & $\begin{array}{l}\$ 1621 \text { al } \\
\$ 1623\end{array}$ & $\begin{array}{l}\text { Pena de prisión de hasta } 5 \text { años y/o } \\
\text { multa. }\end{array}$ & Sí & $\begin{array}{l}18 \text { USC. Extiende la aplicación } \\
\text { no solo a la declaración ante los } \\
\text { tribunales sino al realizado ante } \\
\text { las autoridades competentes bajo } \\
\text { juramento. } \\
\text { Contempla tanto el perjurio } \\
\text { (figura principal) como el falso } \\
\text { testimonio. }\end{array}$ \\
\hline Finlandia & 1995 & $\begin{array}{l}\text { Cap. } 18 \\
\text { Sección } 1^{\text {a }} \\
\text { a la } 5^{\mathrm{a}}\end{array}$ & $\begin{array}{l}\text { Pena de hasta } 3 \text { años de prisión. } \\
\text { En causa criminal o en supuestos } \\
\text { especialmente graves, pena de } \\
\text { prisión de } 4 \text { meses a } 6 \text { años. }\end{array}$ & No & $\begin{array}{l}\text { Recoge un subtipo atenuado que } \\
\text { extiende la aplicación del tipo a } \\
\text { procedimientos similares a los } \\
\text { judiciales. }\end{array}$ \\
\hline Francia & 1992 & $\begin{array}{l}\text { Art. } 434-13 \\
\text { y } 434-14\end{array}$ & $\begin{array}{l}\text { Pena de } 5 \text { años de prisión y multa } \\
\text { Pena de } 5 \text { años de prisión y una } \\
\text { multa superior si es por precio o en } \\
\text { causa penal. } \\
\text { Tipifica el perjurio en causa civil } \\
\text { previendo una pena de } 3 \text { años y } \\
\text { multa. }\end{array}$ & Sí & $\begin{array}{l}\text { Prevé la retractación como } \\
\text { eximente. }\end{array}$ \\
\hline Iraq & 1969 & $\begin{array}{l}\text { Art. } 251 \text { al } \\
\text { art. } 259\end{array}$ & $\begin{array}{l}\text { Pena de detención (de } 3 \text { meses a } 5 \\
\text { años) y multa. } \\
\text { Si es en causa criminal y ha } \\
\text { provocado condena, la misma pena } \\
\text { que correspondería al condenado. }\end{array}$ & Sí & $\begin{array}{l}\text { Recoge expresamente tanto el } \\
\text { falso testimonio como el perjurio. } \\
\text { Es interesante que establece una } \\
\text { pena talional. }\end{array}$ \\
\hline Italia & 1930 & $\begin{array}{l}\text { Art. } 371 \text { al } \\
\text { art. } 374\end{array}$ & $\begin{array}{l}\text { Castiga el falso juramento en causa } \\
\text { civil con la pena de prisión de } 6 \\
\text { meses a } 3 \text { años. } \\
\text { El falso testimonio en causa } \\
\text { judicial ante la autoridad: pena de } \\
\text { prisión de } 2 \text { a } 6 \text { años. }\end{array}$ & Sí & $\begin{array}{l}\text { Establece un tipo que castiga la } \\
\text { información falsa al Fiscal, con } \\
\text { una pena de hasta } 4 \text { años de } \\
\text { prisión. }\end{array}$ \\
\hline Marruecos & 1963 & $\begin{array}{l}\text { Art. } 368 \text { al } \\
\text { art. } 379\end{array}$ & $\begin{array}{l}\text { Pena de } 5 \text { a } 10 \text { años de prisión. } \\
\text { Por causa criminal pena de prisión } \\
\text { de } 10 \text { a } 15 \text { años. }\end{array}$ & No & \\
\hline Portugal & 1982 & $\begin{array}{l}\text { Art } 359 \text { al } \\
\text { art. } 383\end{array}$ & $\begin{array}{l}\text { Falso testimonio de parte, o como } \\
\text { testigo, pena de hasta } 3 \text { años de } \\
\text { prisión. } \\
\text { En causa penal con resultado de } \\
\text { condena y privación de libertad } \\
\text { pena de prisión de } 1 \text { a } 8 \text { años. }\end{array}$ & No & $\begin{array}{l}\text { Subtipos agravados atendiendo a } \\
\text { las consecuencias del falso } \\
\text { testimonio. } \\
\text { Establece asimismo la } \\
\text { retractación como eximente. }\end{array}$ \\
\hline Reino Unido & 1912 & $\begin{array}{l}\text { Art. } 1 \text { al } \\
\text { art. } 16\end{array}$ & $\begin{array}{l}\text { Pena de hasta } 2 \text { años de prisión y/o } \\
\text { multa. }\end{array}$ & Sí & $\begin{array}{l}\text { Regulado expresamente a través } \\
\text { de esta norma: Perjury Act } 1911 .\end{array}$ \\
\hline Rusia & 1995 & Art. 307 al & Falso testimonio de testigos peritos & No & Prevé la retractación y multas \\
\hline
\end{tabular}




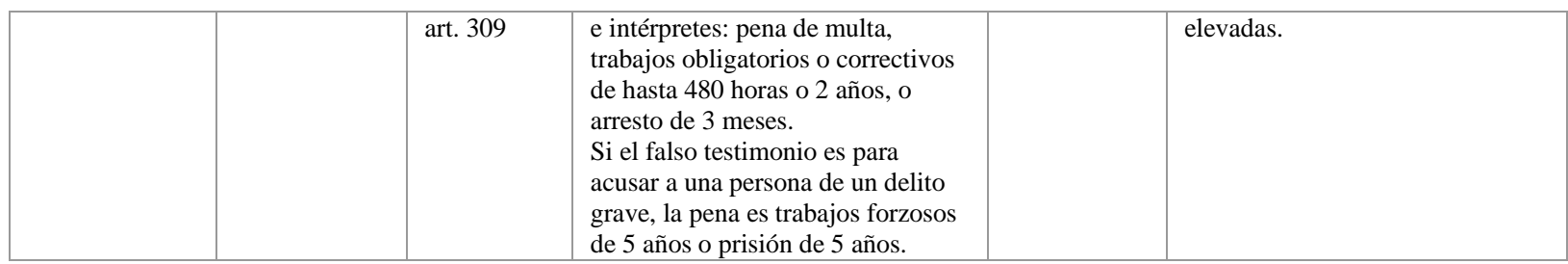

Como es de ver en la tabla anterior, aunque de forma generalizada todos los países acuden a la tipificación del falso testimonio, su regulación presenta notables diferencias de un país a otro. Así, mientras algunos ordenamientos regulan expresamente la retractación del testigo inveraz como causa de exclusión de pena, otras legislaciones no contemplan expresamente esta figura en la Ley; y mientras una mayoría de países solo castiga el falso testimonio en el seno de un proceso judicial, no faltan algunos países en los que el falso testimonio en procesos administrativos o arbitrales, o incluso el falso testimonio prestado ante notario, se halla tipificado ${ }^{16}$.

También se advierten diferencias penológicas significativas entre los distintos ordenamientos: aunque todos los países analizados prevén pena privativa de libertad para las modalidades más graves de falso testimonio, los umbrales de esta pena varían considerablemente de un país a otro. En efecto, si bien vemos que algunos ordenamientos establecen penas de prisión de hasta 12 o 15 años para este delito, encontramos otros muchos más benignos, como el español, en que la pena máxima para la modalidad más grave de falso testimonio es de tan solo 3 años de prisión.

En conclusión, la incriminación del falso testimonio no ha sido solo una constante histórica, sino que constituye también hoy en día una opción política-criminal plenamente vigente y universal, tanto a nivel estatal como supraestatal, como forma de proteger la prueba testifical como instrumento probatorio y para dotar de una mayor legitimidad al propio proceso ${ }^{17}$.

Así las cosas, si los ordenamientos jurídicos de todo tiempo y lugar han coincidido en atribuir al delito de falso testimonio, en el plano de la conminación legal, un papel

\footnotetext{
${ }^{16}$ Algunos ejemplos de dichas especificidades son, por ejemplo, en el Código Penal de Brasil, en el que a través de una reforma del Código Penal introducida en el año 2001se prevé expresamente en el art. 342 la tipicidad del falso testimonio en el proceso judicial, pero también en el administrativo, en las investigaciones policiales y en el procedimiento arbitral. En Portugal, el Art. 359 y 360 del Código Penal, diferencia la falsa declaración efectuada por una de las partes procesales de lo que sería el falso testimonio de testigos, peritos e intérpretes. Resulta también interesante ver el caso colombiano en el que, en los últimos años, y en contra de lo que viene siendo una tendencia generalizada, ha existido una progresiva aseveración de las penas previstas para el falso testimonio.

${ }^{17}$ En la actualidad, encontramos que en los sistemas jurídicos modernos la prueba testifical sigue teniendo reconocido un potencial probatorio muy importante. Los principios que rigen la convicción judicial como son la libre valoración de la prueba, o la convicción subjetiva, permiten reconocer a la prueba testifical una suficiencia probatoria que, en jurisdicciones como la penal, permiten que se pueda alcanzar la convicción judicial en base a la prueba de un testigo único. Cfr. MAGALDI, María José, El falso testimonio, cit. nota $\mathrm{n}^{\mathrm{o}}$ 1, p. 24 y 25; SANCINETTI, Marcelo Alberto, "Testimonio único y principio de la duda." InDret, no 3 (2013), http://www.indret.com/pdf/988.pdf, [visitado el 17.1.2017].
} 
imprescindible en la salvaguarda de la prueba testifical ${ }^{18} \mathrm{y}$, con ello, del sistema de Administración de Justicia ${ }^{19}$, lo que cabría esperar es una activación frecuente de este delito. Pero ¿es lo que ocurre realmente en la aplicación práctica de este delito?

A intentar responder a esta pregunta dedicaremos las páginas que siguen y, como veremos, la respuesta nos confrontará a una paradoja, no pequeña, que suscitará nuevos interrogantes.

\section{Datos empíricos sobre la escasa persecución y punición del delito de falso testimonio. Las cifras de persecución del falso testimonio en España}

De forma generalizada, se ha instalado la percepción en la doctrina de que el testimonio inveraz es una práctica que se da con una notable frecuencia ante nuestros tribunales y que, pese a ello, son pocos los testigos mendaces contra los que se actúa penalmente, y menos aún, los que finalmente son condenados ${ }^{20}$. Con todo, la base empírica de dicha percepción no ha sido explicitada por parte de la doctrina.

En el caso español, esta sospecha -la relativa a la falta de persecución- parece que puede verificarse, aunque sea de forma limitada, a través de los datos que nos muestran las estadísticas oficiales ${ }^{21}$. Reproducimos en la siguiente tabla las cifras de persecución del delito de falso testimonio por parte de nuestros tribunales en los últimos años, desde el año 2012 al $2016^{22}$ :

\footnotetext{
${ }^{18}$ Sobre el papel que, en general, ha desempeñado el delito de falso testimonio -y el perjurio- en derecho histórico, y la influencia que ha tenido la configuración histórica de este delito en la evolución al derecho más moderno véase MILLÁN GARRIDO, "El delito de falso", cit. nota $n^{\circ} 1$.

Respecto a la trascendencia de este delito en derecho anglosajón, a través de la figura del perjurio véase GREEN, Stuart, Mentir, hacer trampas, y apropiarse de lo ajeno. Una teoría moral de los delitos de cuello blanco, Trad.: AGUSTINA, José Ramón; ORTIZ DE URBINA, Íñigo, Madrid: Marcial Pons, 2013, p. 183: "El perjurio fue considerado uno de los delitos más despreciables en el common law. Según William Hawkins, «el perjurio es, entre todos los crímenes, el más infame y detestable». Según el Código de Hammurabi, el Derecho romano y el Derecho medieval francés, la pena por realizar declaraciones falsas era la muerte; en la colonia de Nueva York la pena incluía marcar la letra «P» en la frente del delincuente. En estudios recientes las posturas públicas hacia este delito el perjurio continúa considerándose como un delito muy grave".

${ }^{19}$ En la actualidad, la doctrina mayoritaria afirma que el bien jurídico protegido por los delitos de falso testimonio es el correcto funcionamiento de la Administración de Justicia: cfr. por todos FARALDO/CATALINA/CLEMENTE, El falso testimonio, cit. nota $\mathrm{n}^{\circ}$ 10, p. 138.

${ }^{20}$ Por todos, QUINTERO OLIVARES, Gonzalo, "Del falso testimonio", en QUINTERO OLIVARES, Gonzalo, (Dir.); MORALES PRATS, Fermín (Coord.), et al, Comentarios a la parte especial del Derecho Penal, $10^{\mathrm{a}}$ ed., Cizur Menor: Aranzadi Thomson Reuters, 2016, pp. 1811- 1878, p. 1850. El autor sostiene: "este delito ha sido señalado siempre como una muestra de la tolerancia o de la ineficacia del sistema español, pues siendo, en la apreciación vulgar, alto el número de testigos poco fiables, es muy bajo el de procedimientos penales incoados".

${ }_{21}$ Hay que destacar que, aunque es una postura aislada, parece apuntar en sentido contrario FARALDO/CATALINA/CLEMENTE, El falso testimonio, cit. nota 10, p. 137 y 139. A este respecto podría matizarse lo sostenido por Faraldo, dado que si bien las cifras de los últimos cinco años muestran una tendencia al alza, en términos relativos (teniendo en cuenta lo que se dirá) siguen siendo cifras muy bajas.

${ }^{22}$ Los datos recogidos tienen su origen en diversas fuentes oficiales. Es por ello que hay que señalar que si bien algunos de los datos, en función de la fuente de origen, no coinciden con exactitud con los recogidos por otra fuente, las variaciones son mínimas. Es por ello que, si bien no podemos decir que los datos obtenidos sean un reflejo exacto de los índices de persecución y castigo del delito de falso
} 
Tabla 2: Procedimientos incoados por falso testimonio y número de condenas ${ }^{23}$

\begin{tabular}{|c|c|c|c|}
\hline 运 & 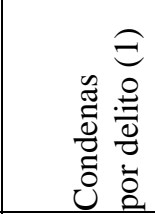 & 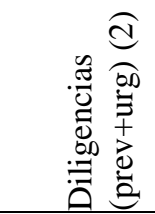 & 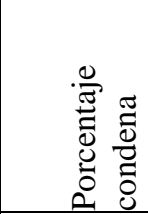 \\
\hline 2016 & 457 & 1625 & $28 \%$ \\
\hline 2015 & 425 & 1486 & $29 \%$ \\
\hline 2014 & 432 & 1548 & $28 \%$ \\
\hline 2013 & 383 & 1661 & $23 \%$ \\
\hline 2012 & 327 & 1753 & $19 \%$ \\
\hline
\end{tabular}

(1) Estadística obtenida a través del INE con los datos del Registro Central de Penados.

(2) Estadística obtenida a través del INE con los datos facilitados por el Consejo General del Poder Judicial (CGPJ), en los que se recogen las cifras que anualmente proporciona la Memoria Anual presentada por la Fiscalía General del Estado. Sólo se han tomado en consideración los procedimientos incoados por falso testimonio que han dado lugar a diligencias previas o urgentes.

A primera vista, tanto el número de procedimientos como el de condenas por falso testimonio parecen significativamente bajos. Sin embargo, de tales cifras no puede deducirse, cuando menos de forma directa, que ello sea fruto de una tendencia generalizada a no perseguir los testimonios presuntamente falsos.

Cabría apuntar al menos dos hipótesis explicativas:

(1) En una primera hipótesis, estas cifras tan reducidas podrían deberse a que la simple conminación penal de este delito es altamente eficaz: con arreglo a esta hipótesis, la razón de que haya relativamente pocos procedimientos y condenas por falso testimonio no sería otra que la escasa frecuencia de su comisión ${ }^{24}$.

testimonio en nuestra realidad jurisdiccional, sí que podemos decir que las cifras reales serán muy similares a las que han sido recogidas en la tabla.

${ }^{23}$ Hay que tener en cuenta que para una aproximación interpretativa hemos recogido los procedimientos incoados por falso testimonio y el número de condenas que se dan a lo largo de un año. Poniendo en relación estas variables en años naturales nos proporciona un porcentaje aproximado de la tasa de condena, pero el porcentaje no será exacto por cuanto parte de los procedimientos cuya incoación hemos atribuido a un año, no tiene por qué haberse enjuiciado en ese mismo año, sucediendo lo mismo con las condenas.

${ }^{24}$ Cfr. MESTRE, Esteban, "Delitos contra la Administración de Justicia", en LAMARCA, Carmen (Coord.), Derecho Penal parte especial, 5a ed., Madrid: Colex, 2010, pp. 639 - 979, p. 640. El autor, aunque de una forma más genérica que FARALDO, interpreta las bajas cifras de persecución de los delitos contra la administración de justicia como algo indicativo de la buena salud general del sistema de la Administración de Justicia. Esta misma postura es la que, de forma minoritaria, mantiene FARALDO, CATALINA, CLEMENTE, El falso testimonio, cit. nota $\mathrm{n}^{\circ} 10$, p. 123 y p.138, dado que sostiene que el nivel de aplicación de los delitos de falso testimonio es bastante superior al que habitualmente le concede la doctrina. 
(2) En una segunda hipótesis - que creemos más acertada-, la escasez de causas incoadas por delito de falso testimonio obedecería a que existe cierta renuencia o pasividad, por parte del sistema de justicia, a la hora de perseguir esta modalidad delictiva ${ }^{25}$.

La primera hipótesis puede ser descartada ab initio por cuanto no solo no se ajusta a lo que se percibe en el trabajo diario de nuestros tribunales (como veremos infra), sino que, además, está en contradicción con lo que nos muestran algunos datos estadísticos.

En efecto, para constatar que el número de procedimientos en los que se persigue y castiga el falso testimonio es bajo, o muy bajo, resulta revelador comparar el número de condenas por delito de falso testimonio con la cifra de condenas por un delito de similares características, como sería el delito de acusación y denuncia falsas ${ }^{26}$.

Así, atendiendo al mayor riesgo y a la mayor complejidad que la conducta de denunciar y acusar en falso conlleva para su autor, podría hipotetizarse que las cifras de este tipo de delito y, por tanto, el número de condenas por acusación y denuncia falsas deberían ser considerablemente inferiores a las de falso testimonio. Además, si tenemos en cuenta que la persecución de estos delitos es más compleja que la del delito de falso testimonio - por las limitaciones establecidas por el legislador ${ }^{27}$-, se podría augurar que el delito de acusación y denuncia falsas tendría un menor índice de condenas que el delito de falso testimonio.

Sin embargo, las cifras reales apuntan en un sentido contrario: en el año 2016, las condenas por acusación y denuncia falsas ascendieron a $3.221 \mathrm{y}$, en el año 2015, a $3.591^{28}$. Si comparamos estas cifras con las 457 y 425 condenas que se dictaron en esos mismos años por delito de falso testimonio, parece claro que se constata que la cifra de

\footnotetext{
${ }^{25}$ Si bien es cierto que, como en la mayoría de delitos, en el falso testimonio también pueden existir una cifra importante de hechos constitutivos de delito que no ponen en marcha un proceso distinto por no existir indicios suficientes de criminalidad, o que nunca llegan a ser detectados, parece que no es solo esta indeterminada "cifra oculta" la que puede explicar los bajos índices de persecución y castigo de estos delitos. En este sentido, son muchas las voces en la doctrina que se han pronunciado. Por todos, QUINTERO, "Del falso testimonio", cit. nota $\mathrm{n}^{\circ} 20$, p. 1850 , el cual viene reclamando una política criminal y judicial más enérgica con el falso testimonio.

${ }^{26}$ En el Código Penal español, dentro del título dedicado los delitos contra la Administración de Justicia, su capítulo $\mathrm{V}$ recoge los delitos de acusación y denuncia falsa, y la simulación de delito -art. 456 y 457 del $\mathrm{CP}-$.

${ }^{27}$ La conducta descrita en el artículo $456 \mathrm{CP}$ tipifica la conducta de quienes imputen falsamente a una persona la comisión de un hecho delictivo, estableciendo una limitación para proceder penalmente a perseguir esta conducta por cuanto requiere que, previamente, exista un auto o sentencia firmes que acuerden el sobreseimiento o el archivo del proceso por la infracción imputada. El artículo 457 castiga a aquellos que simulen ser responsables o víctimas de una infracción penal, o denunciaren una inexistente, en este caso también el legislador impone una limitación a la hora de actuar penalmente ante esta conducta, dado que requiere que haya dado lugar a actuaciones procesales -no bastando, en consecuencia, la simple denuncia-.

${ }^{28}$ Estadística obtenida a través del INE (Instituto Nacional de Estadística) con los datos facilitados por el Consejo General del Poder Judicial, en los que recoge las cifras que anualmente proporciona la Memoria Anual presentada por la Fiscalía General del Estado.
} 
condenas del falso testimonio es significativamente escasa, en comparación con otros delitos semejantes ${ }^{29}$.

Esta cierta pasividad por parte de nuestros tribunales a la hora de perseguir el delito de falso testimonio puede también apreciarse, cuando menos de modo indiciario, comparando el número de diligencias previas que se incoan para perseguir un posible delito de falso testimonio con el número de diligencias previas que se incoan por otros delitos en los que también existe un contenido falsario o un elemento de engaño:

Tabla 3: Comparativa del número de diligencias previas incoadas por falso testimonio y las incoadas por delitos de falsedad en documento privado, en documento público, simulación de delito y estafa

\begin{tabular}{|c|c|c|c|c|c|}
\hline 密 & 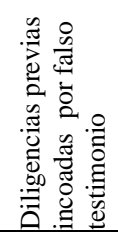 & 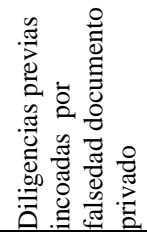 & 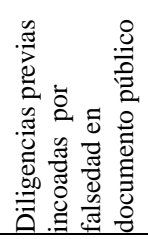 & 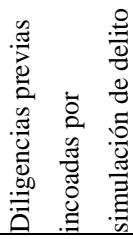 & 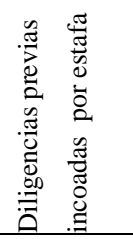 \\
\hline 2016 & 1568 & 1815 & 6589 & 3461 & 62.131 \\
\hline 2015 & 1433 & 1881 & 6831 & 3425 & 164.089 \\
\hline 2014 & 1502 & 2161 & 7194 & 3798 & 154.788 \\
\hline 2013 & 1613 & 2228 & 8776 & 3927 & 144.044 \\
\hline 2012 & 1696 & 2154 & 9521 & 2623 & 142.629 \\
\hline
\end{tabular}

Tras lo visto anteriormente, podemos afirmar que la percepción generalizada de que en España se persigue poco el delito de falso testimonio no es solo una sospecha, sino que se apoya en ciertos indicios. Las cifras que nos proporcionan las estadísticas oficiales nos permiten, pues, constatar que, en términos relativos, los índices de persecución del falso testimonio son significativamente bajos.

Una vez evidenciado este extremo, un segundo paso para conocer un poco más sobre este fenómeno sería tratar de dimensionar la frecuencia con la que intervienen testigos inveraces en nuestros procesos. Para ello, y ante la imposibilidad de conocer la "cifra oculta" 30 de falsos testimonios - por cuanto han conseguido engañar al sistema de

\footnotetext{
${ }^{29}$ Podría objetarse a esta conclusión el hecho de que estamos ante dos delitos distintos en que su persecución obedece a motivaciones distintas y su impulso procesal sigue lógicas bien diversas por cuanto en el delito de acusación y denuncia falsa el primer interesado en poner en marcha el proceso suele ser la propia víctima -o el perjudicado por el delito- mientras que, en el delito de falso testimonio, la mayoría de veces dependerá del órgano de enjuiciamiento o del Ministerio Fiscal. Si bien esta objeción es real, a nuestro criterio también puede resultar ilustrativa a la hora de reforzar la hipótesis planteada con anterioridad, y es que uno de los motivos del porqué de las bajas cifras de incriminación viene a apuntar a la falta de celo perseguidor a la hora de actuar penalmente contra estas conductas por parte de quienes tienen la obligación de hacerlo por imperativo legal -dado que estamos ante un delito perseguible de oficio-, descartando la hipótesis de que el delito de falso testimonio esté desplegando exitosamente su efecto preventivo-general en el plano de la conminación penal abstracta.

${ }^{30}$ Venimos utilizando la expresión "cifra oculta" en detrimento de "cifra negra". En sentido estricto, en el presente caso no nos hallamos ante una "cifra negra". En general, el concepto "cifra negra" se refiere a hechos delictivos que ocurren pero que no llegan a conocimiento del sistema de persecución penal (por
} 
justicia y han pasado inadvertidos, o no existe prueba sobre la que basar su persecución-, lo relevante a los efectos del presente trabajo es tratar de dimensionar la frecuencia con la que los testigos declaran en falso en nuestros procedimientos y, pese a ser detectada la falsedad de sus manifestaciones, ni el Ministerio Público ni el juzgador actúan penalmente contra el falso testigo.

Así, para profundizar en la hipótesis planteada, trataremos de averiguar si los bajos índices de persecución de los falsos testigos que sí han sido detectados -por parte del Ministerio Fiscal, o por parte del juzgador, que han sido testigos directos de las declaraciones mendaces-, están dentro de unos estándares razonables. O si, por el contrario, la escasa persecución de estos delitos es de tal magnitud que nos conduce a constatar la situación paradójica que venimos aduciendo: que los escasos índices de persecución se deben, en gran parte, a un cierto clima de tolerancia de nuestros tribunales con los falsos testigos. En definitiva, que la relevancia que tiene el delito de falso testimonio desde un prisma teórico-legislativo ${ }^{31}$ no se corresponde con la escasa trascendencia que le otorgan nuestros tribunales desde una perspectiva práctica.

En este sentido, si bien para cuantificar el nivel de persecución del delito de falso testimonio sin duda sería de utilidad poner en relación las cifras de incriminación con el número de procesos en los que intervienen testigos como fuente de prueba, lo cierto es que no existe ningún estudio o fuente estadística que nos proporcione el número concreto de procedimientos en los que han intervenido testigos (como única fuente de prueba o junto a otras fuentes de prueba).

Pese a ello, podemos obtener una idea orientativa acerca del nivel de persecución del delito de falso testimonio si tomamos las cifras de incoación de diligencias por este delito, y las ponemos en relación con el volumen global de procedimientos tramitados por nuestros juzgados y tribunales cada año en las jurisdicciones penal y social -por ser en estas jurisdicciones donde la prueba testifical adquiere una mayor relevancia cuantitativa y cualitativamente- ${ }^{32}$.

ejemplo, un abuso sexual o un hurto no denunciado). En cambio, cuando se habla de una escasa cantidad de causas efectivamente incoadas, en general supone que ha existido una causa, esto es, que el hecho delictivo ha llegado a conocimiento del sistema de persecución penal, pero que éste luego no ha operado o no ha terminado con una condena. Son dos fenómenos diferentes. En los delitos contra la Administración de Justicia estaríamos, en realidad, ante la no prosecución de una causa una vez conocidos unos hechos prima facie delictivos. En este contexto y para los delitos de falso testimonio lo importante es que la no denuncia o la no persecución de oficio implican que no se da origen a otro proceso distinto, a pesar del conocimiento acerca del hecho constitutivo de falso testimonio.

31 Sobre el bien jurídico protegido y el objeto de protección, en la actualidad, del delito de falso testimonio, cfr. MARTÍNEZ RUIZ, Jesús, "La criminalidad de los testigos, peritos e intérpretes, a la luz del Código Penal de 1995", Revista de Derecho Penal (Lex Nova), n o 4 (2003), pp. 37 - 66, p. 38 a 46. DOMÍNGUEZ IZQUIERDO, Eva M., "La retractación en el delito de falso testimonio: cuestiones procesales y sustantivas", Cuadernos de Politica Criminal, vol.1, no 88 (2006), pp. 79 - 118, p. 79 y s.

${ }^{32}$ Hay que señalar que no tomaremos en consideración los procedimientos civiles ni contenciosoadministrativos, por cuanto la relevancia de la prueba testifical en tales jurisdicciones es mucho menor que la que tiene en la jurisdicción penal o social, tanto cualitativa como cuantitativamente (son pocos los procedimientos civiles -y menos aún los de lo contencioso-administrativo- en los que la prueba testifical tiene reconocido un papel especialmente determinante a la hora de configurar el resultado del pleito. Es por ello que, siguiendo un criterio prudencial, hemos preferido aplicar nuestro razonamiento a los procedimientos en los que la prueba testifical adquiere un mayor protagonismo tanto cuantitativa como 
Tabla 4: Cifras de persecución y condena del delito de falso testimonio en relación con el volumen de procedimientos ingresados en la jurisdicción social y penal

\begin{tabular}{|c|c|c|c|c|c|c|c|}
\hline 号 & 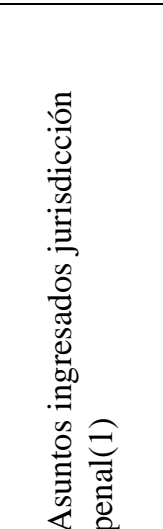 & 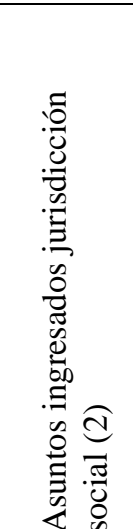 & 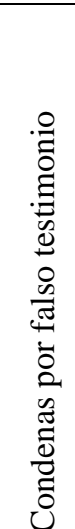 & 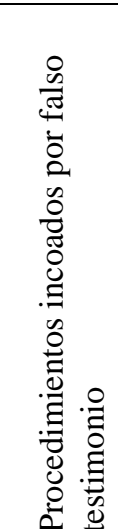 & 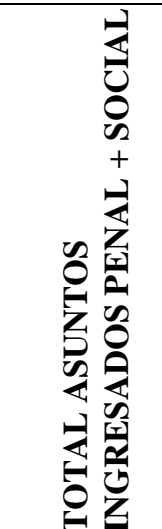 & 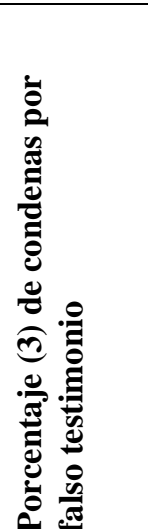 & 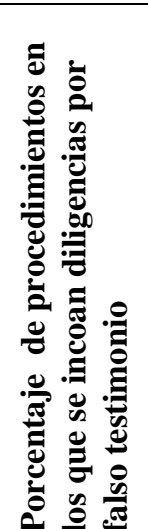 \\
\hline 2016 & 2.752 .448 & 325.161 & 457 & 1625 & 3.077 .609 & $0,0148 \%$ & $0,0528 \%$ \\
\hline 2015 & 5.179 .317 & 345.151 & 425 & 1486 & 5.524 .468 & $0,0077 \%$ & $0,0269 \%$ \\
\hline 2014 & 5.542 .142 & 374.163 & 432 & 1548 & 5.916 .305 & $0,0073 \%$ & $0,0262 \%$ \\
\hline 2013 & 5.665 .526 & 421.043 & 383 & 1661 & 6.086 .569 & $0,0063 \%$ & $\mathbf{0 , 0 2 7 3 \%}$ \\
\hline 2012 & 5.808 .779 & 406.214 & 327 & 1753 & 6.214 .993 & $0,0053 \%$ & $0,0282 \%$ \\
\hline
\end{tabular}

(1) Juzgados de instrucción, Primera instancia e Instrucción, Juzgados de Violencia contra la Mujer y menores. No se tienen en cuenta los ingresados en instancias superiores, ni ejecutorias.

(2) Solo en los Juzgados de lo Social, no se tienen en cuenta ni los del TSJ ni instancias superiores, ni ejecutorias.

(3) Siguiendo un criterio prudencial, este porcentaje se ha calculado atribuyendo todos los delitos de falso testimonio a las jurisdicciones penal y social, por cuanto es en estas jurisdicciones donde la declaración testifical adquiere mayor relevancia.

En efecto, las cifras de investigación y condena de los falsos testigos, puestas en relación con el volumen global de procedimientos, revelan que, a pesar de que los índices de incriminación han experimentado un ligero ascenso en los últimos años, la frecuencia con que se procede a la persecución y castigo de los falsos testigos es considerablemente baja en términos relativos ${ }^{33}$.

cualitativamente, dado que tomar en consideración el global de procesos que se conocen por parte de nuestros tribunales (incluyendo los del orden contencioso-administrativo, y los asuntos civiles) podría llevarnos a unas conclusiones menos fiables, o que podrían llevar a sobredimensionar el fenómeno de la falta de persecución de los falsos testigos. Respecto a la relevancia que en relación con el falso testimonio adquiere la prueba testifical en las distintas jurisdicciones, cfr. MAGALDI PATERNOSTRO, María José, El falso testimonio, cit. nota $\mathrm{n}^{\circ}$ 1, p. 24 y MUÑOZ SABATÉ, Luis, Técnica probatoria, Estudios sobre las dificultades de la prueba en el proceso, $4^{\mathrm{a}}$ Ed., Barcelona: Praxis, 1993, p. 318 y 319.

${ }^{33}$ Estos cálculos se han efectuado utilizando la metodología seguida por la Fiscalía General del Estado, en su memoria de 2013, para abordar el estudio y conclusiones sobre un tema similar que es la incidencia de denuncias falsas en el ámbito de la violencia de género. En este sentido, la fiscalía interpreta las bajas cifras de persecución del delito de acusación y denuncia falsas, en relación al número de denuncias por violencia contra la mujer, como prueba que califica de elocuente de la insignificante incidencia de denuncias falsas en dicho ámbito de enjuiciamiento. Así, en la página 265 sostiene: "El escasísimo porcentaje de causas incoadas cada año por delito de acusación y denuncia falsa en relación al número de denuncias por violencia sobre la mujer interpuestas que supone, es suficientemente elocuente para rebatir las voces que se alzan en torno a la existencia de «denuncias falsas». Si hallamos la proporción en relación a los procedimientos en los que se ha dictado sentencia condenatoria -24 - resulta que solo el 
Así, los datos recogidos en las estadísticas oficiales nos permiten deducir que la persecución y el castigo del testigo inveraz es algo que se da con tan escasa frecuencia que no solo resulta poco probable que se actúe penalmente contra un falso testigo, sino que podría decirse que es algo excepcional. Y es que ciertamente parece poco creíble que en el año 2015, solo en 1 de cada 3.717 procedimientos se diera alguna declaración que revistiera indicios de falsedad; o que solo en 1 de cada 13.000 procedimientos existían elementos suficientes para dictar una sentencia condenatoria por falso testimonio en relación a lo declarado por alguno de los testigos intervinientes.

También se llega a la misma conclusión (las cifras de persecución y castigo del falso testimonio es muy baja en términos relativos) aun aplicando unos criterios mucho más restrictivos. En este sentido, si tomamos las cifras de persecución y condena del delito de falso testimonio y las ponemos en relación con el número de sentencias que se dictan en las jurisdicciones penal y social nos encontramos con los siguientes datos ${ }^{34}$ :

Tabla 5: Cifras de persecución y condena del delito de falso testimonio en relación con el volumen de procedimientos en los que se ha llegado a dictar sentencia en la jurisdicción

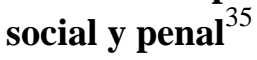

\footnotetext{
0.0045 por 100 se ha acreditado que eran falsas. Si a éstas sumamos las causas en tramitación, para el caso de que resultaran pronunciamientos condenatorios, el porcentaje final máximo será de 0.012 por 100." Si bien utilizamos la sistemática de la fiscalía a la hora de recoger los datos relativos a la incidencia del falso testimonio en nuestros procesos, hay que señalar que nos apartaremos de la interpretación que efectúa de los mismos para fundamentar sus conclusiones. Consideramos que la interpretación que efectúa la fiscalía de los datos estadísticos no es lo suficientemente sólida como para fundamentar las conclusiones alcanzadas, por cuanto los bajos índices de investigación del delito de acusación y denuncia falsa en el ámbito de la violencia de género no tienen por qué deberse a la inexistencia de este tipo de conductas, sino que existen otras hipótesis explicativas de dicha falta de persecución como pueden ser la falta de detección de dichas conductas, la falta de indicios a la hora de proceder a su persecución, o una cierta pasividad a la hora de hacer frente a los mismos.

${ }^{34}$ Cfr. HERNÁNDEZ GARCÍA, Javier; GOYENA HUERTA, Jaime; GRINDA GONZÁLEZ, José, Los delitos contra la administración de justicia. Navarra: Aranzadi, 2002, p.102. Si bien el delito de falso testimonio puede darse en cualquier fase del procedimiento, y tener sus efectos (por ejemplo, dando lugar a un archivo de las actuaciones) no es un hecho habitual que se incoen diligencias por falso testimonio en base a una declaración que no haya sido prestada en el acto de juicio oral.

Es por ello que, aunque desde un punto de vista del tipo no parece que sea exigible que el falso testimonio se haya vertido en el acto de Juicio oral -y por tanto que exista una contradicción entre lo declarado por el testigo y lo fijado en sentencia-, siguiendo las tesis más restrictivas respecto a la interpretación del tipo, como el recogido por Grinda, aun cogiendo solo los procedimientos en los que ha llegado a dictarse sentencia, las cifras apuntan a que es muy bajo el índice de persecución.

${ }^{35}$ En los que, en consecuencia, se presume que se ha llegado a celebrar juicio oral.
} 


\begin{tabular}{|c|c|c|c|c|c|c|c|}
\hline 吕 & 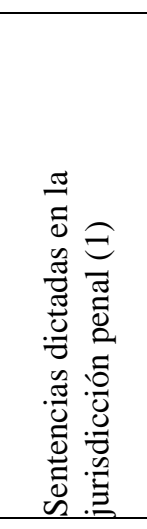 & 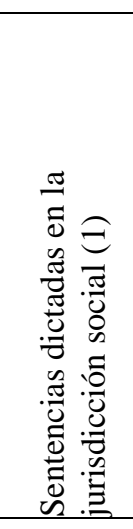 & 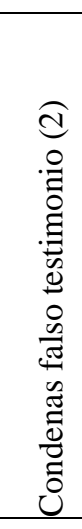 & 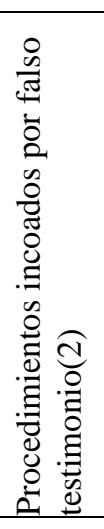 & 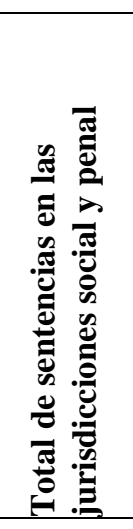 & 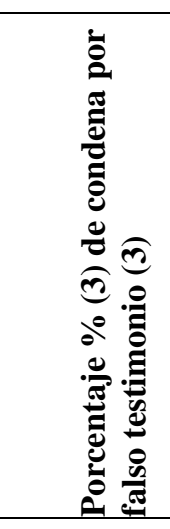 & 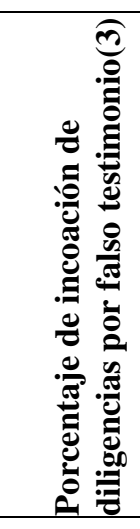 \\
\hline 2016 & 644.693 & 212.119 & 457 & 1625 & 856.812 & $\mathbf{0 , 0 5 3 3 \%}$ & $0,1897 \%$ \\
\hline 2015 & 644.693 & 218.739 & 425 & 1486 & 863.432 & $0,0492 \%$ & $0,1721 \%$ \\
\hline 2014 & 701.066 & 212.049 & 432 & 1548 & 913.115 & $0,0473 \%$ & $0,1695 \%$ \\
\hline 2013 & 714.724 & 217.233 & 383 & 1661 & 931.957 & $0,0411 \%$ & $0,1782 \%$ \\
\hline 2012 & 741.189 & 233.914 & 327 & 1753 & 975.103 & $0,0335 \%$ & $0,1798 \%$ \\
\hline
\end{tabular}

(1) Estos datos se han obtenido del informe que anualmente emite el Consejo General del Poder judicial bajo el título "Justicia Dato a Dato".

(2) Datos obtenidos a través del a través del Instituto Nacional de Estadística (en adelante INE), y que son los facilitados por el Ministerio Fiscal en su memoria anual, como anexos.

(3) Estos porcentajes se han calculado atribuyendo todas las causas por falso testimonio solo al volumen de procedimientos en los que ha llegado a dictarse sentencia, y solo dentro de las jurisdicciones social y penal.

De nuevo, los datos demuestran que la persecución y el castigo de los falsos testimonios es un hecho prácticamente excepcional. Aun aplicando unos parámetros más restringidos vemos que, tomando el año con mayor número de condenas (2016), solo en 1 de cada 527 casos que se enjuician se persigue un posible delito de falso testimonio y solo en 1 de cada 1875 esa declaración inveraz llega a ser penada.

No parece creíble que los datos expuestos sean el reflejo de la cifra real de falsos testimonios efectivamente perpetrados, por cuanto no parece corresponderse con lo que sucede en nuestra realidad jurisdiccional. Piénsese, por ejemplo, en aquellos casos en los que existe una declaración falsa, y sobre los que existe una prueba sólida del carácter mendaz de lo declarado por el testigo, como sería el que lo manifestado por el mismo fuera absolutamente incompatible con lo que posteriormente se declara probado en sentencia. Este hecho - que se da con una cierta habitualidad-, si bien resulta imposible cuantificar su frecuencia exacta, lo que es seguro es que sucede en un porcentaje muy superior al 0,1897 de los casos enjuiciados ${ }^{36}$. En efecto, aunque el delito de falso testimonio no requiere que exista esta contradicción entre la declaración testifical y los hechos probados (por cuanto también resulta típica la conducta cuando un testigo falta a la verdad, por ejemplo, en el modo en que percibió los hechos sobre los que declara -

\footnotetext{
${ }^{36}$ En este sentido basta pensar en la reconstrucción de la prueba de un juicio que acaba posteriormente en condena. Resulta evidente que, con frecuencia, el acusado presenta testigos de descargo en la que basar su defensa y que, con frecuencia, el juez no otorga credibilidad por estar en directa contradicción con otros elementos probatorios.
} 
diciendo que fue testigo directo cuando en realidad era testigo de referencia-, para reformar los medios probatorios que posteriormente conformarán el sentido del fallo) ${ }^{37}$, aún en el hipotético caso de que la condena por este delito pasara por aplicar este criterio restrictivo, el que existan incompatibilidades entre la convicción judicial, plasmada en los hechos probados, y lo que declara alguno de los testigos del proceso, parece evidente que ello tiene lugar con mucha mayor frecuencia que la que indicarían las estadísticas: en 1 de cada 1875 casos.

En consecuencia, pese a que existen unas evidentes limitaciones a la hora de cuantificar la frecuencia con la que se dan falsos testimonios ${ }^{38}$, lo que las estadísticas analizadas nos permiten constatar es que el delito de falso testimonio tiene unos índices de persecución y condena excepcionalmente bajos, tanto si atendemos al volumen de procesos en los que podrían darse este tipo de conductas, como si atendemos a lo que vulgarmente puede apreciarse en relación a la frecuencia con la que deponen falsos testigos en nuestros procesos ${ }^{39}$.

Todo ello viene a confirmar la situación paradójica que venimos anunciando: que a pesar de que normativamente ha existido un importante esfuerzo legislativo a la hora de combatir la amenaza de los falsos testigos, la realidad es que la trascendencia práctica, en cuanto a su persecución, resulta llamativamente insignificante.

Asimismo, dicha situación se evidencia todavía más incongruente si, como planteábamos en una de las hipótesis iniciales, se confirma que la falta de persecución del delito de falso testimonio puede atribuirse a una actitud transigente por parte de nuestros tribunales para con los falsos testigos.

En este sentido parece que, en gran medida, la falta de persecución del delito de falso testimonio sí está relacionada con una cierta pasividad de nuestros tribunales ante este hecho delictivo. Ello es así por cuanto la conducta tipificada en los arts. 458 y siguientes del Código Penal resulta de tal simplicidad que difícilmente puede afirmarse que de ella se deriva una especial dificultad interpretativa que impida, o dificulte de forma significativa, una mayor persecución de estas conductas. Ello además resulta coherente con lo visto anteriormente, y es que de las constantes reformas de las que ha sido objeto el delito de falso testimonio se deduce una importante implicación legislativa a fin de

\footnotetext{
${ }^{37}$ Podemos decir que hay un cierto consenso doctrinal - con independencia de que se sigan tesis objetivas o subjetivas en relación con el concepto de "lo falso" en el testimonio-, y un cierto consenso jurisprudencial, acerca de la tipicidad de la conducta del testigo miente en cómo percibió los hechos relatados (diciendo por ejemplo que fue testigo ocular, cuando en realidad no lo fue), pese a que su declaración coincida con lo que sucedió realmente constituirá delito de falso testimonio por cuanto parte de su testimonio -la afirmación de haber sido testigo presencial- no se ajusta a la realidad. Cfr. DEL MORAL GARCÍA, Antonio., "Delitos contra la administración de justicia” en DEL MORAL GARCÍA, Antonio (Coord.); SERRANO BUTRAGUEÑO, Ignacio (Coord.), et al, Código Penal, Comentarios y jurisprudencia, Granada: Comares, 2002, p. 2494.

38 Cfr. HERNÁNDEZ GUIJARRO, "Naturaleza del delito", cit. nota no 13, p. 333: "Sorprende, ciertamente, que la casi totalidad de los delitos de falso testimonio, necesariamente cometidos a la presencia judicial, flagrantes por naturaleza, estén comprendidos en la llamada "cifra negra"”.

${ }^{39}$ Por todos QUINTERO, Comentarios a la parte especial, cit. nota $\mathrm{n}^{\circ} 20$, p. 1850. El autor sostiene: "siendo, en la apreciación vulgar, alto el número de testigos poco fiables, es muy bajo el de procedimientos penales incoados".
} 
que el delito de falso testimonio constituya un instrumento eficaz con el que proteger la Administración de Justicia ${ }^{40}$.

Con lo dicho anteriormente no pretendemos ignorar que existen algunas cuestiones interpretativas relacionadas con el delito de falso testimonio que sí han dado lugar a un importante debate dogmático y doctrinal como son, por ejemplo, la definición del bien jurídico protegido por la norma ${ }^{41}$, su configuración como delito de peligro ${ }^{42}$, o el debate que se suscita en relación con las teorías de la falsedad ${ }^{43}$. Si bien es cierto que estas

\footnotetext{
${ }^{40}$ A este respecto resulta especialmente sugerente atender a la evolución que han ido experimentando los delitos de falso testimonio desde la época de la codificación hasta la actualidad en los ocho Códigos Penales que se han aprobado con posterioridad. Cfr. FARALDO/CATALINA/CLEMENTE, El falso testimonio, cit. nota $\mathrm{n}^{\circ} 10$, pp. 123-137.

${ }^{41}$ La definición de lo que constituye el bien jurídico protegido por el delito de falso testimonio ha dado lugar a distintos posicionamientos doctrinales. En este sentido, y de forma resumida, podríamos decir que, aunque existe un cierto consenso en que el bien jurídico consiste en el correcto funcionamiento de la Administración de Justicia, esta definición resulta tan vaga e imprecisa que suscita un profundo $-\mathrm{y}$ relevante- debate a la hora delimitar el mismo a través de su concreción. Cfr. MAGALDI, El falso testimonio, cit. nota $\mathrm{n}^{\circ} 1$, p. 32 Cfr. FARALDO/CATALINA/CLEMENTE, El falso testimonio, cit. nota $\mathrm{n}^{\mathrm{o}}$ 10, p. 138 ss. En este sentido Faraldo, siguiendo a otros autores, afirma que el bien jurídico protegido por el delito de falso testimonio es el normal funcionamiento de la actividad o función jurisdiccional encomendada a jueces y tribunales, el correcto funcionamiento del proceso, la preservación de los fines del proceso, la pureza o veracidad de los medios probatorios, e incluso la "certeza de la prueba procesal" y la "pureza de la aportación de los hechos" o de la fase probatoria en un proceso judicial.

${ }^{42}$ Cfr. KINDHÄUSER, "Estructura y legitimación", cit. nota ${ }^{\circ}$ 2. Podemos ver que a pesar de que hay un consenso doctrinal respecto a que estamos ante un delito de peligro -como forma de anticipación de la tutela penal-, existen diversas teorías por lo que se refiere a su especificidad. Unos sostienen, por ejemplo, que la configuración del delito corresponde a la de delito de peligro abstracto Cfr. CEREZO MIR, "Los delitos de peligro abstracto en el ámbito del derecho penal del riesgo", Revista de Derecho penal y Criminología, $\mathrm{n}^{\circ} 10$ (2002), pp. 47 - 72. Otros afirman que se trata de un delito de peligro de mera actividad Cfr. MAGALDI, El falso testimonio, cit. nota $\mathrm{n}^{\circ}$ 1, p. 34. Algunos matizan que se trataría de un delito de peligro abstracto, pero para bienes institucionales. Hay quien lo califica de delito de peligro abstracto, pero sobre bienes supraindividuales; o quien entiende que el delito de falso testimonio se configura como delito de peligro, o de lesión, dependiendo del bien jurídico intermedio Cfr. FARALDO/CATALINA/CLEMENTE, El falso testimonio, cit. nota $\mathrm{n}^{\circ}$ 10, pp. 141-142. Finalmente, hay quien lo califica de delito de lesión-peligro: Cfr. DOMINGUEZ, El delito de falso testimonio, cit. nota ${ }^{\circ}$ 1, p. 180.

${ }^{43}$ También la cuestión dogmática relativa a las teorías de la falsedad, proyectada en la declaración testifical, ha sido una cuestión que ha suscitado un amplio debate por parte de la doctrina española y inernacional: cfr. STEIN, Ulrich, "Acerca del concepto de declaración falsa", Trad.: KISS, Alejandro, Revista electrónica de ciencia penal y criminología, vol. 10, no 15 (2008) pp. 1-26; WILENMANN VON BERNATH, Javier, "El concepto de falsedad en el falso testimonio, una introducción a la dogmática general de los delitos de falsedad", Revista Chilena de Derecho, vol. 41, no 1 (2014), pp. 59 - 88. Ante esta cuestión, dos grupos de tesis se enfrentan en este punto: las objetivas, que consideran que la declaración será falsa si no se ajusta a la realidad, y las subjetivas, que sostienen que será también falsa la declaración que, aun ajustándose a la verdad, no refleja el conocimiento del sujeto: entre muchos otros, cfr. DEL MORAL, Código Penal, Comentarios, cit. nota n 37, p. 2494; TORÍO, "Introducción", cit. nota $\mathrm{n}^{\mathrm{o}} 1$, p. 20. Torío señala que el problema fundamental de la falsedad viene referido a determinar si consiste en una contradicción entre realidad y declaración o, por el contrario, entre declaración y ciencia del sujeto. Si bien las diferentes posturas se han ido modulando y convergiendo alcanzando zonas de consenso, lo cierto es que, aunque parece que las existe una mayor inclinación hacia la teoría objetiva, es una cuestión que sigue abierta. En la doctrina española encontramos ejemplos de los distintos posicionamientos: parecen decantare a favor de una teoría objetiva de lo falso, MAGALDI, El falso testimonio, cit. nota $\mathrm{n}^{\circ} 1$, pp. 76 s., DEL MORAL, Código Penal, Comentarios, cit. nota $\mathrm{n}^{\circ}$ 37, p. 2494, TORÍO, "Introducción", cit. nota no 1. p. 20 s, QUINTERO, Comentarios a la parte especial, cit. nota ${ }^{\circ}$ 20, p. 1850-1851 y en sentido contrario encontramos a BERNAL VALLS, Jesús, El falso testimonio, Madrid: Tecnos, 1992, p. 103.
} 
cuestiones podrían tener alguna repercusión práctica a la hora de promover (o no) la acción penal por una declaración mendaz, no parece que puedan justificar las bajas cifras de persecución vistas anteriormente.

Ello es así por cuanto aunque existe un debate que afecta a lo que constituye la conducta típica y al alcance de este tipo penal ${ }^{44}$, aun entendiendo que dichas cuestiones pudieran justificar en alguna medida la falta de persecución de estas conductas por parte de nuestros tribunales, lo cierto es -como veremos- que ello solo afectaría a un número reducido de posibles falsos testigos, pero no alcanzaría a justificar la actitud de nuestros tribunales ante un gran número de testigos mendaces que, pese haberse detectado el contenido mendaz de sus declaraciones, quedarían impunes por cuanto no son ni tan siquiera objeto de persecución.

Asimismo debemos añadir que esta situación de falta de proactividad a la hora de proceder contra los falsos testigos parece que ni es un problema nuevo ${ }^{45}$, ni exclusivo de nuestro sistema jurisdiccional. Así, la doctrina de diversos países viene pronunciándose acerca de problemas similares en relación a los falsos testigos, tanto por su importante prevalencia como por su impunidad en sede jurisdiccional ${ }^{46}$.

\footnotetext{
${ }^{44}$ Véase por ejemplo SILVA SANCHEZ, Jesús María, en SALVADOR CODERCH, Pablo; SILVA SANCHEZ, Jesús María, Simulación y deberes de veracidad. Derecho civil y derecho penal: dos estudios de dogmática jurídica, Madrid: Cuadernos Civitas, 1999, p. 77 y s. A este respecto Silva sostiene que las manifestaciones inveraces solo son punibles en la medida en que respondan a los elementos propios del «modelo» de estafa, y que la falta de veracidad de los particulares puede ser sancionada en la medida en que constituyen el medio de producir un perjuicio a un tercero, y en los casos en los que el ordenamiento jurídico ha establecido deberes especiales -como es el caso del falso testimonio- que recaen sobre algunos, o incluso sobre todos los particulares. Añade Silva que tales deberes especiales se conectan a la creación de determinados riesgos especiales para intereses fundamentales, o a la ostentación de posiciones jurídicas determinadas, o ambas cosas.

${ }^{45}$ RODRÍGUEZ ENNES, "La prueba testifical", cit. nota $n^{\circ}$ 8, p. 833: "si bien las normas del antiguo Derecho castellano castigaban con severidad el falso testimonio, al igual que acaece en nuestros días, el precepto punitivo quedaba en pura letra muerta. Destaca que de la misma forma que ocurre hoy, la aglomeración de pruebas, y al existir entonces las mismas condiciones y causas que en la actualidad -la aglomeración de trabajo, lo rutinario y desesperante de la mayoría de las probanzas, la dispersión en el tiempo de este tipo de pruebas, que requería que el juez tuviese en la mente en todo momento la totalidad de los pleitos- las soluciones, prácticamente, serían las mismas que ahora: dejar a un lado la norma y encauzar de la mejor forma posible la actividad judicial, en la manera más operativa que se pudiese".

Véase también, ALEJANDRE, "El delito de falsedad testimonial", cit. nota no 4, p. 10.

En Estados Unidos, desde hace años la doctrina viene apuntando en el mismo sentido que hemos visto. En este sentido WHITMAN, Alfred David, "A proposed solution to the problem of perjury in our courts", Dickinson Law Review, vol. 57 (1954), pp. 127 - 149, p.127 Señala que el perjurio en el sistema americano es un problema grave común y reconocido por la doctrina de forma unánime citando otros pronunciamientos doctrinales anteriores: Problems os Successful Perjury, 78 Sol. J. 423 (1934)- apunta: "Hundreds of persons perjure themselves in the court every day except Sunday", también citando a H.L. Mc CLINTOCK, What Happens to Pejurers, 24 Minn. L. Rev. 727 (1940) "The opinion that perjury is common in our trial courts is one on which all of the writers on the quesiton seem to be in complete agreement" señala asimismo que "Few crimes except fornication are more prevalent or carried off with greater impunity".

${ }^{46}$ DOUGLIS, Allison, "Disentangling Perjury and Lying", Yale JL \& Human, vol. 29 (2017), pp. 339 374 , p. 353. Señala que solo 87 de los 50.000 casos criminales que se inician por el fiscal federal están relacionados con el perjurio. La autora cita el artículo de SURO, Roberto; MILLER, Bill, Perjury: A tough Case to Make, Washington Post, sept. 24, 1998, A14.

Asimismo, HEINRICH, Alan, "Clinton's Little White Lies: The Materiality Requirement for Perjury in Civil Discovery”, Loyola of Los Angeles Law Review, vol. 32 (1998), pp. 1303 - 1356, en
} 
En consecuencia, y en relación a la hipótesis planteada, todo parece apuntar a que uno de los principales motivos de la escasez de causas incoadas por delito de falso testimonio es la existencia, en efecto, de una voluntad renuente, o una ausencia de recursos (o energías), por parte del sistema para combatir este tipo de delitos. Además, como veremos a continuación, esta cierta pasividad por parte de nuestros tribunales ante los falsos testigos no solo se deduce de todo lo visto con anterioridad, sino que viene siendo secundado por diversos pronunciamientos doctrinales, y puede ser constatado a través de lo que recogen las propias resoluciones judiciales.

\section{Análisis doctrinal y jurisprudencial de la escasa persecución y castigo del falso testimonio: establecimiento indiciario de las causas en la indulgencia o pasividad de los operadores jurídicos}

\footnotetext{
http://digitalcommons.lmu.edu/llr/vol32/iss4/19 [visitado el 17.1.2018], pp. 1316 - 1319. Resulta especialmente relevante las referencias estadísticas que aporta esta autora sobre el perjurio en Estados Unidos. Sostiene que, si es cierto que las cifras de perjurio son elevadas, la baja persecución sistemática del tipo delictivo socaba su efecto disuasorio, por lo que sostiene que convendría que los fiscales incrementaran su persecución para fomentar su efecto disuasorio. Asimismo, son diversos los pronunciamientos de la doctrina americana en el mismo sentido, señalando la imposibilidad de conocer a ciencia cierta el volumen de falsos testimonios que se dan en los juicios, pero mantienen que la apreciación forense es que esta práctica es generalizada, y que no solo atenta contra los conceptos básicos de los procesos judiciales, sino que amenaza la administración imparcial y eficaz de la justicia, así como a la integridad de los tribunales. Cfr. SHELLENBERGER, James A., "Perjury Prosecutions After Acquittals: The Evils of False Testimony Balanced Against the Sanctity of Determinations of Innocence", Marquette Law Review, vol. 71, n ${ }^{\circ} 4$ (1988), pp. 703 - 747, p. 705-706. En países con raíces en derecho continental encontramos que también se da una problemática muy similar en relación con la incriminación del falso testimonio. Por ejemplo, en Colombia han tenido que tomar medidas para luchar contra los falsos testigos en los procedimientos judiciales dado que ya no solo constituía una amenaza, sino que ha devenido un importante problema a nivel institucional. En este sentido hay que destacar que, además de incrementarse sensiblemente las penas previstas para el falso testimonio en el año 2004, el Fiscal General de la Nación, mediante la Resolución número 01566 de 2012, de 4 septiembre, conformó un grupo de trabajo para la investigación de falsos testigos. En la misma se puede leer: "Que la Fiscalía General de la Nación ha detectado la existencia de falsos testigos, que están actuando de manera indiscriminada, extorsionando a la comunidad so pretexto de enlodar su buen nombre a través de testimonios mentirosos. Que por lo anterior se hace necesario, crear un grupo de trabajo conformado por fiscales, asistentes e investigadores del C.T.I., para que se encargue de adelantar las investigaciones, formulando las acusaciones cuando a ello hubiere lugar, ante los jueces competentes, por los delitos de falso testimonio, fraude procesal y los demás en que puedan incurrir los falsos testigos ”. En Costa Rica, Cfr. BURGOS, Álvaro, "La mentira forense. Los delitos de perjurio y falso testimonio en el Código Penal de Costa Rica", Revista de Ciencias Jurídicas, n ${ }^{\circ} 121$ (2010), pp. 165 - 186, p. 184. Respecto al falso testimonio y el perjurio, Burgos señala que son dos delitos de suma importancia, pero sin embargo cada vez más aumentan los casos. Considera asimismo que no son delitos que puedan ser combatidos en papel, al escribirlos en una norma, sino que han de ser manejados de forma que se fortalezca la enseñanza de valores y éticas de convivencia en sociedad, para que poco a poco las futuras generaciones crezcan respetando estos principios de honestidad y respeto. Por su parte, en Argentina, es de destacar la crítica vertida respecto al tratamiento de los falsos testigos por parte de ADIP, Prueba de testigos, cit. nota $\mathrm{n}^{\circ} 10$, p.11. Y, finalmente, para conocer la situación en Francia, véase GORPHE, François, La crítica del testimonio, Trad.: RUIZ FUNES, Mariano, Madrid: Ed. Reus, 2013.
} 
Como ya se ha adelantado, en el ámbito español, buena parte de la doctrina viene denunciando lo que es una percepción forense generalizada: que es bajo el nivel de aplicación de los delitos de falso testimonio si se pone en relación con el alto número de testigos falsos que se estima que debe de haber en las causas judiciales ${ }^{47}$. También vienen apuntando la gravedad de esta falta de persecución si se tiene en cuenta que la infracción que comete el falso testigo es una infracción que además de llevarse a cabo públicamente, se realiza ante unos testigos de excepción ${ }^{48}$.

En efecto, a pesar de que, como hemos visto, existe una notable preocupación legislativa a fin de combatir la amenaza que constituyen falsos testigos para el proceso, y a pesar de que la doctrina viene pronunciándose de forma reiterada compartiendo dicha preocupación, resulta llamativo ver que los operadores judiciales -el Poder Judicial, y el Ministerio Público- no se han pronunciado de forma clara acerca de la envergadura y la trascendencia que se reconoce al problema de los falsos testigos, ni públicamente han anunciado medidas para combatir su incidencia.

Podría decirse que donde el legislador y la doctrina se han pronunciado reconociendo en el falso testimonio un problema de notable relevancia - por la frecuencia con la que la mendacidad irrumpe en el proceso a través de las falsas testificales-, desde los operadores judiciales existe una cierta reticencia a la hora de manifestarse acerca de la trascendencia que reconocen dicho problema.

Ello es así, y se deduce, por ejemplo, de lo que recogen las Memorias de la Fiscalía General del Estado ${ }^{49}$. A pesar de que analiza los datos relativos al delito de falso testimonio, y que de ellos se desprende un escaso índice de persecución, lo habitual es que su análisis se limite a unas breves líneas genéricas, sin que profundice ni plantee ninguna línea de actuación para hacer frente al problema.

Así, en la última Memoria de Fiscalía de 2017, se hace una pequeña alusión a la importancia que tendrían que darse a este tipo de delitos, y reconoce que los datos no parecen revelar una actuación muy eficaz. En la Memoria de 2014 se viene a hacer un reconocimiento indirecto de la falta de persecución del delito de falso testimonio, pero de una forma imprecisa, estableciendo que, "si fuera más relevante la presencia de delitos contra la Administración de Justicia, ello sería eficaz para afirmar la organización interna del sistema judicial". Asimismo, se limita a apuntar, de forma genérica, "a la conveniencia de que asentarse una cultura que interiorice que el mentir a

\footnotetext{
${ }^{47}$ Por todos, véase QUINTERO, Comentarios a la parte especial, cit. nota $\mathrm{n}^{\circ}$ 20, p. 1850; CARRASCO ANDRINO, María del Mar, "La falsedad en el dictamen pericial o en la traducción del intérprete en causa judicial”, Cuadernos de Política Criminal, Número 110, Época II (2013), pp. 5 - 51, p. 7; DOMÍNGUEZ IZQUIERDO, "La retractación", cit. nota $\mathrm{n}^{\circ}$ 31, p. 81 y 82; BERNAL VALLS, Jesús, "el falso testimonio: cuestiones procesales y sustantivas", en: SERRANO BUTRAGUEÑO, Ignacio, et al, Delitos contra la administración de justicia, Granada: Editorial Comares, 1995, pp. 148 - 230, p. 159 y s.; MUÑOZ SABATÉ, Técnica probatoria, Cit. nota $\mathrm{n}^{\circ}$ 32, p. 330.

${ }^{48}$ DOMÍNGUEZ IZQUIERDO, El falso testimonio de testigos, cit. nota no 1, p. 38 y s.

${ }^{49}$ La Memoria de la Fiscalía General del Estado es un informe que anualmente se presenta a presenta a las Cortes Generales, en el que se recoge la actividad del Ministerio Fiscal de forma anual, así como la evolución de la criminalidad, la prevención del delito y las reformas convenientes para una mayor eficacia de la Justicia.
} 
la Administración de Justicia en cualquier tipo de pleito, el no comparecer, el intimidar a las partes, el acusar falsamente o el incumplir sus determinaciones tienen una sanción penal que se impone de forma habitual" 50 .

Sin embargo, pese a esta renuencia, existe algún pronunciamiento en publicaciones dependientes del CGPJ $^{51}$-publicación Cuadernos de Derecho Judicial, del Consejo General del Poder Judicial del año 1997-, en el que de forma excepcional se reconoce la existencia de una problemática en torno a la prueba testifical y los falsos testigos. Si bien resulta evidente que no es una posición oficial acerca del alcance del problema, sí que resulta esclarecedor por su inusitada franqueza, aportando una visión clara y realista sobre la ineficacia del delito de falso testimonio, y sobre la aplicación práctica del mismo desde la óptica del juzgador.

En este sentido, Viera Morente justifica la reforma del delito de falso testimonio introducida en el año $1995^{52}$ por la devaluación de la prueba testifical en la práctica judicial. Reconoce asimismo la desconfianza generaliza de los Tribunales de Justicia en la fiabilidad de la prueba testifical, y respalda la percepción de que existe un debilitamiento del compromiso natural de los testigos a ser veraces.

Esta realidad, que con crudeza -y a nuestro entender, con gran acierto- expone Viera Morente, podemos verla refrendada, aunque de forma mucho más retraída, en algunas resoluciones judiciales ${ }^{53}$.

\footnotetext{
${ }^{50}$ Memoria de Fiscalía de 2017, p. 837; Memoria de Fiscalía de 2014 p. 686.

${ }^{51}$ Nos referimos a la publicación Cuadernos de Derecho Judicial, del Consejo General del Poder Judicial del año 1997, y en concreto al capítulo desarrollado por VIERA MORENTE, Francisco J., "El falso testimonio, cambios introducidos por el Código Penal de 1995 e influencia de la Ley del Tribunal del Jurado", en: CADENAS CORTINA, Cristina (Dir.), et al., Delitos contra la administración de justicia, Madrid: Cuadernos de Derecho Judicial, Escuela Judicial, Consejo General del Poder Judicial, 1997, pp. $235-278$, p. 233 y s.

${ }^{52}$ En el capítulo dedicado al delito de falso testimonio, el autor justifica la modificación respecto a los cambios introducidos en el Código penal de 1995 diciendo: El nuevo Código penal ha podido contribuir de algún modo a aplicar un mayor rigor al delito de falso testimonio, al menos en la medida que ha clarificado determinadas cuestiones discutidas con la anterior normativa y ha ampliado el ámbito de aplicación de esta figura penal, tanto en el aspecto objetivo, como en el subjetivo, como luego veremos." Estos cambios se preveían de inicio que fueran de gran calado, pueden resumirse en que: el tipo básico de falso testimonio se refiere en general a causa judicial, no a causa civil, e incluye también el juicio de faltas; el falso testimonio en causa criminal por delito de limita al que se da en contra del reo, quedando el falso testimonio a favor del reo o indiferente para sus intereses en el tipo básico; se mantiene el tipo superagravado del falso testimonio en causa criminal por delito si hubiera recaído sentencia condenatoria; se extiende el falso testimonio al presentado ante Tribunales Internacionales y al realizado en España al declarar en virtud de comisión rogatoria remitida por un tribunal extranjero; se mantiene el tipo agravado a los peritos, con la novedad de que se extiende expresamente a los intérpretes; se mantiene el falso testimonio impropio; también se mantiene el delito de presentación de testigos y peritos falsos, que se extiende a los intérpretes e incluye la presentación de documentos falsos, y se recoge una previsión expresa de la retractación. Cfr. FARALDO/CATALINA/CLEMENTE, El falso testimonio, cit. nota $\mathrm{n}^{\circ}$ 10, p. $133 \mathrm{~s}$.

${ }^{53}$ Cfr. Sentencia del Tribunal Supremo (Sala de lo Penal) no 318/2006 de 6 de marzo, "Digamos que este delito de falso testimonio tiene una gran importancia como delito contra la Administración de Justicia, pues la declaración prestada por los testigos tiene por objeto acreditar o desacreditar las diversas tesis mantenidas en un proceso por las partes litigantes, de modo que la contrapartida de un falso testimonio reside en la carga negativa penal que ha de conferirse a faltar a la verdad en aquello que le fuere
} 
En este sentido, la doctrina viene apuntando que esta escasa persecución de los falsos testigos en gran medida se puede atribuir a que en la práctica judicial existe un clima de indulgencia hacia los mismos ${ }^{54}$, y que se ha instaurado en los órganos jurisdiccionales una praxis que lleva a la infrecuente o nula aplicación de esta figura delictiva ${ }^{55}$.

Como consecuencia de lo anterior, se ha venido reclamando una política criminal más enérgica en relación con el falso testimonio ${ }^{56}$, por cuanto sus consecuencias no se corrigen simplemente confiando en la buena intuición de los juzgadores ${ }^{57}$.

A este respecto, cabe decir que si bien en determinados casos puede existir una cierta dificultad a la hora de detectar y perseguir al testigo mendaz, lo que parece que la doctrina viene denunciando no es tanto que existan testigos inveraces que no son descubiertos -a los que antes nos hemos referido como "cifra oculta" del delito de falso testimonio-, sino el hecho de que exista una percepción generalizada de impunidad de estas fraudulentas conductas cuando además, como hemos visto, no parece que del tipo penal se deriven unas dificultades específicas que impidan promover su persecución ${ }^{58}$.

Con todo, lo cierto es que este clima de indulgencia hacia los falsos testigos no deja de ser una sospecha generalizada en el ámbito forense, sobre el que además se ha pronunciado la doctrina. Si bien todo ello puede ser un indicio que nos invita a creer que la cifra de falsos testigos en nuestros procesos es elevada, lo cierto es que no se ha podido realizar una constatación empírica que permita cuantificar los delitos de falso

preguntado al testigo, deduciéndose el oportuno tanto de culpa ante la jurisdicción penal. Observamos que dicha contrapartida no se exige con el necesario rigor en la práctica de los Tribunales".

En el mismo sentido se pronuncia la Sentencia del Tribunal Supremo (Sala de lo Penal, Sección $1^{\mathrm{a}}$ ) Sentencia núm. 159/2014 de 11 marzo, y el Auto de la Audiencia Provincial de Barcelona, sec.2 $2^{\mathrm{a}}$, de fecha 26 de noviembre de 2001.

${ }^{54}$ CARRASCO, "La falsedad en el dictamen", cit. nota $n^{\circ} 47$, p. 7: "No son pocos los autores que se refieren al descrédito, sobre todo en el ámbito civil y laboral, de la prueba testifical y pericial, que achacan a diversas causas: desde la complejidad de los procesos psicológicos de almacenamiento y recuperación de la memoria hasta las malas prácticas de los abogados, sin olvidar el escaso compromiso de la propia Administración de Justicia en la persecución de los delitos de falso testimonio”.

${ }^{55}$ Cfr. DOMÍNGUEZ IZQUIERDO, El falso testimonio de testigos, cit. nota $\mathrm{n}^{\circ}$ 1, p. 39.

${ }^{56}$ Cfr. QUINTERO, Comentarios a la parte especial, cit. nota no 20, p. 1850; MUÑOZ SABATÉ, Técnica probatoria, Cit. nota $\mathrm{n}^{\circ} 32$, p. 330.

57 Respecto a las consecuencias que el falso testimonio puede tener si se acomoda en el proceso es interesante la opinión de Gorphe, en la que apunta no solo a la posibilidad de error, si no a la inseguridad que supone para el propio sistema judicial. En este sentido, GORPHE, La crítica del, cit. nota ${ }^{\circ}$ 46, p. 10: "Encontramos en este aspecto al Juez entregado por el legislador a sus propios medios, a la vena que tenga o que se le suponga; estamos por decir, que a su instinto de adivinación. Honor excesivamente difícil" "Cualquiera que sea el valor que se quiera conceder a la intuición, se sabe que es extremadamente variable, según los individuos, y que este modo de conocimiento, esencialmente subjetivo y falible, no puede bastarse a sí mismo".

Véase también, DOMÍNGUEZ IZQUIERDO, "La retractación" cit. nota n 31, p. 81.

${ }^{58}$ BERNAL VALLS, El falso testimonio, cit. nota n' 43, p. 21: "Ciertamente, esta general creencia en la sanción penal para el falso testimonio no va acompañada, si nos atenemos a los datos de la experiencia, de una eficaz represión de lo que constituye, según una muy generalizada opinión, un comportamiento frecuente en la vida judicial. A él se refería Hernández Guijarro cuando recordaba que el falso testimonio tiene lugar en público y ante testigos de excepción, sin que, por otra parte, su acreditación resulte más problemáticas que cualquier otro delito." 
testimonio contra los que podría actuarse penalmente y que, pese a ello, no se lleva a cabo actuación penal alguna contra los mismos.

Sin bien, como hemos visto resultaría imposible cuantificar con exactitud la frecuencia con que los tribunales se muestran pasivos ante el falso testimonio. No obstante, lo que sí podemos constatar a través del examen de las resoluciones judiciales es que existe un importante grado de indiferencia o tolerancia frente a las declaraciones que se evidencian falsas, existiendo una renuencia a la hora de actuar penalmente contra los falsos testigos.

En este sentido, pese a que son pocas las ocasiones en las que las resoluciones judiciales hacen alusiones explícitas a posibles falsos testimonios ${ }^{59}$, resulta revelador examinar los razonamientos que se recogen en sentencias dictadas en el enjuiciamiento de algunos tipos delictivos en los que, con mayor frecuencia, se dan declaraciones objetivamente falsas. Este es el caso, por ejemplo, del enjuiciamiento de casos de compra-venta de estupefacientes a pequeña escala.

De estas resoluciones sí se puede deducir, con claridad, el alto grado de tolerancia que se ha instaurado en el enjuiciamiento de estos $\operatorname{casos}^{60}$. Debemos apuntar que a pesar de que puede considerarse que los argumentos que se vierten en las sentencias por tráfico de estupefacientes solo ayudan a constatar que los tribunales se muestran pasivos ante los falsos testigos en ese ámbito de enjuiciamiento, lo cierto es que resultan relevantes por cuanto estos procesos no solo se llevan a cabo con mucha frecuencia ${ }^{61}$ sino que,

\footnotetext{
${ }^{59}$ Tal y como hemos apuntado anteriormente, por lo general, existe una cierta renuencia por parte de los tribunales a la hora de admitir públicamente la problemática entorno a los falsos testigos. Como consecuencia podemos apreciar en las resoluciones judiciales que existe cierta reticencia a hacer alusión explícita a posibles falsas testificales a las que no ha otorgado valor probatorio. Ello, en nuestro sistema, viene siendo favorecido por el principio de libre valoración de la prueba por cuanto, si bien las sentencias son explícitas a la hora de analizar en qué prueba basan su juicio de convicción, no suelen ser tan escrupulosas a la hora de analizar aquellos medios probatorios que no han influido en el mismo.

${ }^{60}$ Así, podemos ver que se viene admitiendo de forma generalizada en las sentencias, y citamos como ejemplo algunas recientes. SAP de Vizcaya (Sección 2a) Sentencia núm. 5/2017 de 26 enero, AP de Navarra (Sección 2a) Sentencia núm. 115/2015 de 26 junio, AP de Madrid (Sección 15a) Sentencia núm. 590/2016 de 31 octubre, AP de Lleida (Sección 1a) Sentencia núm. 10/2017 de 16 enero, AP de Cádiz (Sección 4a) Sentencia núm. 369/2016 de 30 diciembre.

${ }^{61}$ En el año 2016, se dictaron 3690 sentencias por delito de tráfico de drogas sin grave riesgo para la salud, siendo que este grupo estadísticamente estaría situado en el $n^{\circ} 16$ de los tipos delictivos donde se dictan más sentencias, dentro de los 216 grupos de delitos en los que clasifica las sentencias que se han dictado durante ese año. Estos datos han sido obtenidos de las estadísticas que facilita el INE, a través del CGPJ, en los que recoge los datos contenidos en los anexos de las Memorias de Fiscalía:
}

SENTENCIAS/DELITOS CON MAYOR PREVALENCIA ESTADÍSTICA EN 2016

\begin{tabular}{|l|l|}
\hline TIPO DE DELITO SENTENCIADO & No SENTENCIAS \\
\hline Conducción bajo la influencia de alcohol/drogas & $\mathbf{5 0 . 5 5 3}$ \\
\hline Conducción sin licencia/permiso & $\mathbf{2 5 . 6 5 2}$ \\
\hline Lesiones & $\mathbf{1 7 . 7 1 6}$ \\
\hline Violencia doméstica y de género. Lesiones y maltrato familiar & $\mathbf{1 6 . 0 6 4}$ \\
\hline Quebrantamiento condena o medida cautelar (Todos los supuestos) & $\mathbf{1 4 . 9 2 1}$ \\
\hline Robo con fuerza en las cosas & $\mathbf{1 3 . 4 9 1}$ \\
\hline
\end{tabular}


además, son procedimientos en los que los hechos enjuiciados y las pruebas a practicar son, por lo general, muy estereotipados ${ }^{62}$.

En la celebración de las vistas de juicio oral en estos procesos lo habitual es que el comprador, que comparece al acto de juicio en calidad de testigo, no solo niega haber comprado la sustancia estupefaciente, sino que lo hace pese a saber que su falsa declaración queda en evidencia por cuanto se contradice con la de la policía. En estos casos lo habitual es que el juzgador no otorgue credibilidad a lo declarado por el comprador, en tanto que su declaración como testigo queda en entredicho cuando acuden a declarar sendos policías, agentes que no solo han sido testigos directos de la transacción, sino que también declaran que procedieron a la detención del vendedor, a la identificación del comprador y a la incautación de la sustancia.

Pese a ser estos falsos testimonios una realidad que se da a diario en nuestros tribunales, resulta llamativo que las propias sentencias, al referirse a estos concretos testimonios que presentan claros visos de falsedad, no van más allá de reconocer la frecuencia con que se dan los falsos testimonios en este tipo de procedimientos, sin acordar a continuación la deducción de testimonio para que se proceda contra ese presunto falso testigo $^{63}$.

\begin{tabular}{|l|l|} 
Hurto (Conductas varias) & $\mathbf{1 2 . 1 6 0}$ \\
\hline Estafa (Todos los supuestos) & $\mathbf{5 . 9 0 4}$ \\
\hline Robo con violencia o intimidación & $\mathbf{5 . 7 2 7}$ \\
\hline Atentado & $\mathbf{5 . 4 0 3}$ \\
\hline Amenazas (todos los supuestos no condicionales) & $\mathbf{4 . 7 6 4}$ \\
\hline Violencia en el ámbito familiar. Amenazas & $\mathbf{4 . 5 0 6}$ \\
\hline Violencia doméstica y de género. Maltrato habitual & $\mathbf{4 . 5 0 1}$ \\
\hline Daños & $\mathbf{4 . 4 1 6}$ \\
\hline Resistencia o grave desobediencia a autoridad y agentes & $\mathbf{4 . 4 0 5}$ \\
\hline Tráfico de drogas sin grave daño a la salud & $\mathbf{3 . 6 9 0}$ \\
\hline
\end{tabular}

${ }^{62}$ Los hechos a los que nos referimos enjuiciados en estos procedimientos por tráfico de drogas a pequeña escala son todos muy similares. Como ejemplo transcribimos un fragmento de la STS (Sala de lo Penal, Sección $1^{a}$ ) $n^{o}$. 829/2016 de 3 noviembre "resulta que los agentes de policía, declaran haber realizado vigilancias en las que comprobaban que unas personas entraban en el local en el que el acusado trabajaba como camarero, permanecían un escaso tiempo en el interior y lo abandonaban, siendo luego interceptadas y registradas, encontrándose en su poder las pequeñas cantidades de droga que se mencionan en el relato fáctico. Uno de estos agentes, el identificado con el $\mathrm{n}^{\circ}$ NUM002, afirmó que el recurrente era la única persona que estaba en el establecimiento cuando se producían esas entradas. Aunque algunos compradores negaron haber comprado al acusado la droga que se les ocupaba por los agentes, uno de ellos reconoció que la compró en el interior del establecimiento, que pagó diez euros, que solo había una persona de origen marroquí que vendía en el bar y hacía funciones de camarero en la barra".

${ }^{63}$ Hay que destacar que, por lo general, este tipo de manifestaciones no dan lugar ni tan siquiera a una reprobación por parte de los tribunales. En el improbable caso de que el juez acuerde la deducción de testimonio de particulares por la declaración inveraz del comprador de la sustancia, la posición que viene adoptando el Ministerio Público es la de incoar Diligencias de Investigación para, posteriormente, acordar su archivo. Este criterio podemos verlo en el Decreto de Archivo n ${ }^{\circ}$ 87/17 dictado por el Servicio de Diligencias de Investigación de la Fiscalía de Barcelona, de 21 de marzo de 2017. "En definitiva, la manifestación del testigo comparecido se ha revelado ciertamente como inveraz. Sin embargo, dadas las especiales características que envuelven su testimonio, para entender cometido el delito de falso 
En efecto, podemos ver que hasta el propio Tribunal Supremo viene adoptando tal postura: pese a reconocer la falsedad del contenido de dicha prueba testifical y poner de relieve que es un fenómeno habitual, no lleva a cabo acción alguna para promover la persecución y el castigo de la misma.

\begin{abstract}
"En definitiva, negar la realidad, encubriendo al suministrador de la sustancia tóxica, elimina todos los riesgos posibles, salvo una remota y poco probable condena por falso testimonio. Por todo ello, el testimonio de un adicto comprador para acreditar una transacción implicando al vendedor no ofrece garantías y se halla desacreditado ante los Tribunales de justicia, según nos muestra la experiencia judicial diaria. La poca relevancia de ese testimonio, permitiría entenderlo en el sentido más favorable al reo y aun así, no tendría repercusión en la convicción del Tribunal, ya formada a través de otras pruebas más serias y fiables.

En igual sentido las SSTS núm. 150/2010 de 5.3, 792/2008 de 4.12 y 125/2006 de 14.2, ya precisaron que no es necesario para desvirtuar el principio de presunción de inocencia complementar los elementos incriminatorios con el testimonio de los adquirentes de la droga porque éstos "suelen negarse a identificar a sus proveedores por el tenor de represalias y por la necesidad de continuar en el futuro acudiendo a los mismos mercados ilícitos para abastecerse de mercancía para satisfacer su propio consumo" ${ }^{64}$.
\end{abstract}

A través de este tipo de resoluciones se constata que es un hecho frecuente en la práctica forense que se den situaciones como las anteriormente descritas, en las que el testigo decide faltar a la verdad, y ello a pesar de las advertencias de poder incurrir en un delito de falso testimonio, a pesar de saber que el carácter mendaz de su declaración resulta evidente -por contradecirse con otro medio probatorio con mayor credibilidad-, y pese a no obtener un beneficio relevante con su falsa deposición ${ }^{65}$.

Aunque sistemáticamente esta evidente falta de eficacia del tipo penal solo se pueda constatar en procedimientos como los descritos anteriormente, esta realidad nos invita a pensar que si el delito de falso testimonio no logra prevenir y evitar que se produzcan falsas declaraciones como las descritas anteriormente, tampoco será de gran eficacia preventiva frente a aquellos falsos testimonios más sofisticados en los que el testigo sí obtiene un beneficio o persigue un interés con su falsa declaración; o cuando las falsedades de sus declaraciones resulten más sutiles o difícilmente demostrables.

testimonio será necesario que tal manipulación de la realidad sea susceptible de generar un peligroso potencial para el fin del proceso, lo que no ocurrió en el presente supuesto con su declaración al no conferirle el Juzgador la virtualidad necesaria para poder inducirle a error provocando con ello una resolución injusta".

${ }^{64}$ Sentencia Tribunal Supremo (Sala de lo Penal, Sección $1^{\text {a }}$ ) Sentencia núm. 159/2014 de 11 marzo.

${ }^{65}$ Hay que señalar a este respecto que la postura de los tribunales a la hora de no actuar contra este tipo de delitos viene a justificarse a través de un razonamiento de dudosa legalidad. En efecto, escudados en una posible causa de justificación -el comprador de la droga tiene miedo a represalias, o no quiere quedarse sin su proveedor de sustancia- declinan emprender acciones legales contra los mismos, haciendo una presunción ex ante de la existencia de dicha causa de justificación. Además, lo que sería una causa de justificación parece que los Tribunales la están llevando de facto, a la categoría de la tipicidad por cuanto vienen considerándola atípica, basándose en la falta de reconocimiento de credibilidad por parte del tribunal. 
En efecto, al igual sucede con los testigos cuya falsa deposición resulta insignificante para el buen fin del proceso, son muchas las ocasiones en que se sospecha de la existencia de una actitud transigente por parte de nuestros tribunales ante testigos que faltan a la verdad en su declaración cuando ésta puede ser relevante para el enjuiciamiento de los hechos.

También podríamos decir que no es un hecho extraño o aislado, el recurrir al falso testimonio para hacer un uso fraudulento de la justicia con ánimo de perjudicar a otro. Así, a diario se formulan acusaciones que, cuando menos, son sospechosas de estar sustentadas en una falsa declaración de la víctima -que declara como testigo-, dado que tras activarse la maquinaria de la justicia la misma se reputa falsa, dando lugar a la libre absolución del acusado o, en el mejor de los casos, al sobreseimiento y archivo de las actuaciones.

En efecto, existen indicios que apuntan a la existencia de un alto grado de permisividad de nuestros tribunales ante posibles falsos testimonios más o menos complejos, y que puedan tener algún interés o beneficio en el pleito, o cuya falsa declaración pueda tener mayor incidencia en la convicción. Sin embargo, a la hora de constatar la realidad y relevancia de este grado de permisibilidad de nuestros tribunales para con estos falsos testigos, nos encontramos con importantes dificultades metodológicas.

Ello es así por cuanto, al realizar un análisis de los razonamientos jurisprudenciales puede apreciarse que, por lo general, las sentencias tienden a justificar su decisión haciendo mayor hincapié en aquella prueba que sí ha tenido mayor relevancia a la hora conformar su convicción, y tienden a ser menos explícitas a la hora de analizar la prueba que no le ha llevado a conformar la misma. A esto hay que añadir que cuando existen pruebas testificales a las que el juzgador no ha otorgado relevancia por resultar refutados los hechos objeto de la controversia por otros medios probatorios, en nuestra opinión, parece que existe una cierta prudencia argumentativa a la hora de ser categóricos acerca de la falsedad de la testifical, o de su posible ambigüedad.

No obstante, y a pesar de las limitaciones metodológicas, no hace falta hacer búsquedas excesivamente complejas en las bases de datos jurisprudenciales ${ }^{66}$ para encontrar supuestos en los que, tras la valoración de la prueba testifical, el Tribunal reconoce unas serias dudas acerca de la veracidad de la misma. A continuación, señalamos algunos ejemplos:

"De tal manera y a la luz del criterio anteriormente expuesto, del examen que se
lleva a cabo de todas las declaraciones de la testigo, presunta víctima de los hechos,
puede extraerse que la misma no dice la verdad al exponer la forma de suceder los
hechos, dando lugar a su fantasía con ánimo de justificar las consecuencias que,
estimaba, le serían perjudiciales dentro de las circunstancias en que se produjeron,
relaciones con una persona de color, miedo a tener un embarazo... y sus

\footnotetext{
${ }^{66}$ A través de la búsqueda universal de la base de datos Westlaw - Thomson Reuters-, se ha introducido el término "ausencia de credibilidad". Las sentencias cuyos fragmentos transcribimos están sacados de los veinte primeros resultados que nos arroja dicha búsqueda.
} 
consecuencias." Sentencia de la Audiencia Provincial de Almería (Sección 2a núm. 353/2001 de 21 noviembre.

"Este Tribunal duda de la credibilidad de la versión de la denunciante y ello sobre la base de las manifestaciones realizadas en el Fundamento de Derecho ${ }^{67}$ anterior respecto a los elementos que hacen dudar este Tribunal sobre el posible sobredimensionamiento de las secuelas que dice padecer la denunciante." Sentencia de la Audiencia Provincial de A Coruña (Sección 2a ${ }^{\mathrm{a}}$ ) núm. 432/2014 de 23 julio.

"El testigo Juan Luis, uno de los clásicos deponentes de cargo en el sumario reabierto, quien todo lo sabe de referencia, desde que en marzo de 1984 estaba en prisión como fracasado activista del GAL, compareció ante el Tribunal en la segunda sesión del juicio oral (3 de junio, hojas 7 a 13 del acta), y causó imborrable impresión de incredibilidad e insinceridad, habiendo de ser corregido por la Presidencia por no ocultar que escogía al albur entre sus variadas contradictorias manifestaciones en el sumario de las que se le hacía mención, y contestaba a las preguntas sin rigor, y en ocasiones, mediante la impresión más cristalina de estar inventando una respuesta (hoja 11 del acta)..." "En resumen, y al margen de la inexistente credibilidad, es decir, de la aptitud para transmitir la veracidad de lo verosímil, Juan Luis no se reputa sincero por el Tribunal..." "Los datos relevantes son esa falta de respeto hacia la jurisdicción que revelan determinados testigos, que se han preocupado de hacer inviable el recto hallazgo de la verdad, y que dio origen a las Diligencias Previas $n^{\circ}$ 2546/00 del Juzgado de Instrucción $\mathrm{n}^{\circ} 5$ de Bilbao, provisionalmente sobreseídas, y las alusiones, de las que pueden encontrarse tantas huellas en el sumario, de un «montaje «que orquestaba a tales testigos con cargo a conocido Letrado, de lo que hay noticia de prensa, a la que han hecho alusión los testigos Ramón y Alexander, a raíz de una denuncia de Virginia". Sentencia de la Audiencia Provincial de Vizcaya (Sección

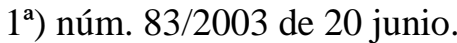

En resumen, siendo la única prueba incriminatoria la declaración de la víctima y estimando esta Sala por todo lo alegado que no es suficientemente creíble ni convincente ante las serias dudas que se suscita, no puede ser tenida en cuenta como única base de la condena interesada por las acusaciones, procediendo dictar una sentencia absolutoria respecto al procesado Guillermo. Sentencia de la Audiencia Provincial de Teruel (Sección 1ª) núm. 2/2012 de 31 enero.

\footnotetext{
${ }^{67}$ En el fundamento jurídico la Sentencia reconoce, entre otros motivos que: "La posibilidad de un sobredimensionamiento del alcance de la lesión se pone también de manifiesto cuando la denunciante en el Plenario a preguntas de la acusación particular declara que si tapa el ojo derecho no ve nada, no distingue ni la claridad, cuando sin embargo los Médicos Forenses a preguntas de la Presidenta del Tribunal manifestaron que si los potenciales evocados visuales son normales se percibe el destello luminoso, se percibe la iluminación y ello mediante la constatación objetiva de que el cerebro reacciona ante el estímulo luminoso aplicado sobre el ojo. Del mismo modo, otro dato que hace dudar a este Tribunal sobre la exactitud del cuestionado diagnóstico de ceguera, es que, en un período de 24 horas, a la denunciante se le realiza por dos veces el test de Ishihara dando en ojo derecho el resultado de 20 sobre 20 y en ojo izquierdo primero da que no ve ni el 12, y la segunda vez que solo ve el 12, cuando dicho test no mide la agudeza visual sino únicamente la alteración en la percepción de los colores que no consta diagnosticada."
} 


\begin{abstract}
"A la vista de lo anteriormente expuesto, esta Sala mantiene dudas importantes sobre la verosimilitud de la declaración de Piedad, que impide atribuirle la condición de prueba de cargo sobre la que basar la condena, faltando así la convicción segura y sin reservas de que la relación sexual impuesta por Bernardo en contra o sin la voluntad de Piedad." Sentencia de la Audiencia Provincial de Valladolid (Sección 2a) núm. 312/2009 de 30 septiembre.
\end{abstract}

Debemos poner de manifiesto que a pesar de lo evidente de las falsas declaraciones efectuadas por algunos de los testigos que depusieron en los casos referidos -de las que, además, alguna de las partes del proceso pretendía sacar algún provecho-, en ninguna de las sentencias relacionadas se dedujo testimonio de particulares para investigar un posible delito de falso testimonio - ni por el tipo básico del art. $458 \mathrm{CP}$, ni por el tipo atenuado que castiga las reticencias del art. $460 \mathrm{CP}$, ni de presentación de testigo falso del art. $461 \mathrm{CP}_{-}{ }^{6}$.

A través de todo lo visto anteriormente podemos afirmar que si bien existe una tendencia legislativa constante y universal a la hora de acudir al delito de falso testimonio como medio necesario para reforzar la administración de justicia, se da la paradoja de que esta preocupación legislativa no viene siendo compartida por nuestros tribunales por cuanto no solo son muy bajos los índices de persecución y punición de los falsos testimonios sino que, además, las bajas cifras de incriminación de los testigos inveraces en cierta medida vienen siendo favorecidas por haberse instaurado un importante grado de pasividad por parte de los Tribunales a la hora de perseguir penalmente las falsas testificales.

Podríamos decir que la falta de compromiso por parte de los operadores judiciales a la hora de perseguir penalmente a los testigos inveraces es un hecho que ha favorecido que, a día de hoy, el delito de falso testimonio haya quedado relegado a desempeñar una función simbólica y de escasa eficacia disuasoria.

Vista esta realidad, resulta ineludible adentrarnos a conocer cuáles pueden ser las causas que dan lugar a esta paradójica situación en la que los principales protegidos por la norma -los jueces encargados de administrar justicia- parecen despreciar, con su pasividad, los medios de protección que quiere proporcionarle su protector, en este caso, el legislador. Este aspecto será objeto de ulteriores trabajos.

\title{
Conclusión
}

\footnotetext{
${ }^{68}$ Tanto el Ministerio Fiscal como los tribunales vienen sosteniendo que para que exista delito de falso testimonio es necesario que el Juez confiera a la falsa declaración la virtualidad necesaria para poder inducirle a error, provocando con ello una resolución injusta -decreto de archivo emitido por la Fiscalía Provincial de Barcelona, de 21 de marzo de 2017, en las diligencias de investigación 87/17-. En sentido opuesto encontramos se manifiesta parte de la doctrina, entre ellos CEREZO MIR, "Los delitos de peligro", cit. nota $\mathrm{n}^{\circ} 42$, p. 72. Sostiene Cerezo Mir que sí debe ser punible la simple realización de acciones que generalmente ponen en peligro el bien jurídico, es decir la simple realización de la acción descrita en el tipo, sosteniendo que en el delito de falso testimonio se debe castigar la simple acción de faltar a la verdad en la testifical, por el hecho de que el sujeto que lo comete no puede saber cuándo el testimonio mendaz crea el peligro de que se dicte una resolución injusta.
} 
En este trabajo hemos tratado de presentar, en toda su dimensión paradójica, el llamativo contraste existente entre la importante función sistémica que, en todo tiempo y lugar, se ha venido atribuyendo al delito de falso testimonio por parte de los legisladores, y la relativamente escasa persecución de este delito que se advierte en la práctica forense. Asimismo, hemos intentado descartar con distintos argumentos que esa escasa activación del delito obedezca o corresponda a las cifras y prevalencia reales del fenómeno de los testimonios mendaces. Queda sin embargo por determinar cuáles son las causas y motivos de distinto orden que pueden explicar esta aparente contradicción: aunque algunos/as pueden intuirse a través de los pronunciamientos doctrinales y jurisprudenciales que se han dejado expuestos, la cuestión habrá de merecer un mayor estudio en futuros trabajos.

En realidad, muchas son las cuestiones que, a partir del presente trabajo, interesaría abordar en relación al falso testimonio. Muchas de ellas, no obstante, requerirían un enfoque multi- e interdisciplinar no exento de dificultades metodológicas y prácticas. En particular, convendría realizar un estudio criminológico sobre las distintas tipologías de inveracidad en el ámbito forense que distinguiera, entre otros aspectos: los distintos motivos que mueven al testigo a mentir; el contenido ético-moral y significado inculpatorio o exculpatorio de su declaración -en la línea apuntada por Green ${ }^{69}$; el resultado finalmente producido (teniendo en cuenta no solo la tentativa de engaño con respecto al órgano de enjuiciamiento, sino también en relación a otros bienes jurídicos, como el honor o la intimidad); la fenomenología y explicación psicológica de posibles inveracidades no advertidas por el declarante ${ }^{70}$, etc. Todas esas distintas perspectivas de análisis podrían ayudar, en definitiva, a definir con mayor precisión las estrategias político-criminales en relación a la configuración del tipo o tipos penales, los estándares de prueba y a los criterios de oportunidad vigentes en la reacción y persecución de las mentiras en sede judicial por parte de quienes tienen el deber de decir verdad.

\footnotetext{
${ }^{69}$ GREEN, Mentir, hacer trampas, cit. nota 18, p. 230 y s.

${ }^{70}$ Véase, al respecto, la sugerente obra sobre psicología del testimonio de MAZZONI, Giuliana, ¿Se puede creer a un testigo? El testimonio y las trampas de la memoria, Madrid: Editorial Trotta, 2003.
} 


\section{Bibliografía}

ADIP, Amado, Prueba de testigos y falso testimonio, Buenos Aires: Ediciones Depalma, 1977.

ALEJANDRE GARCÍA, Juan Antonio, Falsedad documental y falsedad testimonial. Estudio histórico-jurídico de dos tipos delictivos, Madrid: Dykinson, 2012.

ALEJANDRE GARCÍA, Juan Antonio, "El delito de falsedad testimonial en el Derecho histórico español”, Historia, instituciones, documentos, n³ (1975), pp. 9 - 140.

AMIGO ROMAN, Carlos, "El falso testimonio: aspectos jurídicos procesales y derecho comparado", Revista vasca de derecho procesal y arbitraje, n 2 (2010), pp. 279 $-314$.

BENLLOCH, Guillermo, "Delitos contra la Administración de Justicia", en: SILVA SÁNCHEZ, Jesús María (Dir.); RAGUÉS, Ramón (Coord.), Lecciones de Derecho penal. Parte especial, $4^{\text {a }}$ ed., Barcelona: Atelier Libros Jurídicos, 2015, pp. $387-414$.

BURGOS, Álvaro, "La mentira forense. Los delitos de perjurio y falso testimonio en el Código Penal de Costa Rica", Revista de Ciencias Jurídicas, ${ }^{\circ} 121$ (2010), pp. $165-186$.

BENTHAM, Jeremy, Tratado de las pruebas judiciales, tomo I, Trad.: GOMEZ DE CASTRO, José, Madrid: Imprenta de Tomás Jordán, 1835.

BERNAL VALLS, Jesús, El falso testimonio, Madrid: Tecnos, 1992.

BERNAL VALLS, Jesús, "El falso testimonio: cuestiones procesales y sustantivas", en: SERRANO BUTRAGUEÑO, Ignacio, et al, Delitos contra la administración de justicia, Granada: Editorial Comares, 1995, pp. 148 - 230.

CARRASCO ANDRINO, María del Mar, "La falsedad en el dictamen pericial o en la traducción del intérprete en causa judicial", Cuadernos de Política Criminal, Número 110, Época II (2013), pp. 5 - 51.

CASTILlO GONZALEZ, Francisco, El delito de falso testimonio, San José de Costa Rica: Juricentro, 1982.

CEREZO MIR, José, "Los delitos de peligro abstracto en el ámbito del Derecho Penal del riesgo", Revista de Derecho Penal y Criminología, no 10 (2002), pp. 47 - 72.

DEL CARPIO, Juana, "Las víctimas como testigos en el Derecho Penal Internacional. Especial referencia a los Tribunales ad hoc", Política criminal, Vol 8, $\mathrm{n}^{\circ} 15$ (2013), $\quad$ pp. $128 \quad-\quad 169, \quad$ en: http://www.politicacriminal.cl/Vol_08/n_15/Vol8N15A4.pdf [visitado el 17.1.2017].

DEL MORAL GARCÍA, Antonio., "Delitos contra la administración de justicia" en DEL MORAL GARCÍA, Antonio (Coord.); SERRANO BUTRAGUEÑO, Ignacio (Coord.), et al, Código Penal, Comentarios y jurisprudencia, Granada: Comares, 2002.

DOUGLIS, Allison, "Disentangling Perjury and Lying", Yale JL \& Human, vol. 29 (2017), pp. 339 - 374.

DOMÍNGUEZ IZQUIERDO, Eva M., El falso testimonio de testigos, peritos e intérpretes, Madrid: Editoriales de Derecho Reunidas, 2002.

DOMÍNGUEZ IZQUIERDO, Eva M., "La retractación en el delito de falso testimonio: cuestiones procesales y sustantivas", Cuadernos de Política Criminal, vol.1, ${ }^{\circ}$ 88 (2006), pp. 79 - 118. 
FARALDO CABANA, Patricia; CATALINA BENAVENTE, María Ángeles; CLEMENTE DÍAZ, Miguel, El falso testimonio de testigos, peritos e intérpretes, Valencia: Tirant lo Blanch, 2016.

GORPHE, François, La crítica del Testimonio, Trad.: RUIZ FUNES, Mariano, Madrid: Ed. Reus, 2013.

GREEN, Stuart, Mentir, hacer trampas, y apropiarse de lo ajeno. Una teoría moral de los delitos de cuello blanco. Trad.: AGUSTINA, José Ramón; ORTIZ DE URBINA, Íñigo, Madrid: Marcial Pons, 2013.

HEINRICH, Alan, "Clinton's Little White Lies: The Materiality Requirement for Perjury in Civil Discovery", Loyola of Los Angeles Law Review, vol. 32 (1998), pp. 1303 - 1356, en http://digitalcommons.lmu.edu/llr/vol32/iss4/19 [visitado el 17.1.2018].

HERNÁNDEZ GARCÍA, Javier; GOYENA HUERTA, Jaime; GRINDA GONZÁLEZ, José, Los delitos contra la administración de justicia, Navarra: Aranzadi, 2002.

HERNÁNDEZ GUIJARRO, José Julián, "Naturaleza del delito de falso testimonio", Anuario de derecho penal y ciencias penales, vol. 20, no 1 (1967), pp. $333-350$.

KINDHÄUSER, Urs, "Estructura y legitimación de los delitos de peligro del Derecho penal", Trad.: PASTOR, Nuria, InDret 1 (2009), pp. 1 - 19, en: http://www.indret.com/pdf/600.pdf [visitado el 17.1.2017].

LEVENE, Ricardo, El delito de falso testimonio, Buenos Aires: Ediciones Depalma, 1975.

LÓPEZ ANDINO, Juan Antonio, "Sobre el delito de falso testimonio en el marco de un procedimiento arbitral", Anuario de justicia alternativa: derecho arbitral, $\mathrm{n}^{\mathrm{o}} 7$ (2006), pp. 107 - 127.

MAGALDI PATERNOSTRO, María José, El falso testimonio en el sistema penal español, Barcelona: Promociones Publicaciones Universitarias, 1987.

MARTÍNEZ RUIZ, Jesús, "La criminalidad de los testigos, peritos e intérpretes, a la luz del Código Penal de 1995.", Revista de Derecho Penal (Lex Nova), n o 4 (2003), pp. $37-66$.

MAZZONI, Giuliana, ¿Se puede creer a un testigo? El testimonio y las trampas de la memoria, Madrid: Editorial Trotta, 2003.

MESTRE, Esteban, "Delitos contra la Administración de Justicia", en LAMARCA Carmen (Coord.), Derecho Penal parte especial, $5^{\mathrm{a}}$ ed., Madrid: Colex, 2010, pp. $639-679$.

MILLÁN GARRIDO, Antonio, "El delito de falso testimonio", Separata de

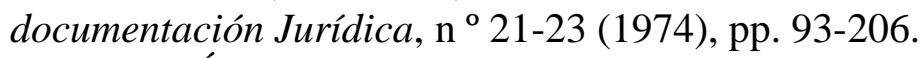

MUÑOZ SABATÉ, Luis, Técnica probatoria, Estudios sobre las dificultades de la prueba en el proceso, $4^{\text {a }}$ Ed., Barcelona: Praxis, 1993.

QUINTERO OLIVARES, Gonzalo, "Del falso testimonio", en QUINTERO OLIVARES, Gonzalo, (Dir.); MORALES PRATS, Fermín (Coord.), et al, Comentarios a la parte especial del Derecho Penal, 10 ${ }^{\mathrm{a}}$ ed., Cizur Menor: Aranzadi Thomson Reuters, 2016, pp. 1811- 1878.

RODRÍGUEZ ENNES, Luis, "La prueba testifical y algunas circunstancias modificativas de la responsabilidad penal en Roma y en el antiguo régimen", en CASTÁN PÉREZ-GÓMEZ, Santiago, et al. Homenaje al Profesor Armando Torrent, Madrid: Dykinson, 2016, pp. 829 - 944.

ROTH, Marianne, "Consequences and Prevention of False Evidence Under the English Arbitration Act 1996: A Comparative Perspective", Arbitration International, Vol. 13, n ${ }^{\circ} 4$ (1997), pp. $391-397$. 
SANCINETTI, Marcelo Alberto, "Testimonio único y principio de la duda", InDret, $\mathrm{n}^{\circ}$ 3 (2013), http://www.indret.com/pdf/988.pdf, [visitado el 17.1.2017].

SALVADOR CODERCH, Pablo; SILVA SANCHEZ, Jesús María, Simulación y deberes de veracidad. Derecho civil y derecho penal: dos estudios de dogmática jurídica, Madrid: Cuadernos Civitas, 1999.

SHELLENBERGER, James A., "Perjury Prosecutions After Acquittals: The Evils of False Testimony Balanced Against the Sanctity of Determinations of Innocence", Marquette Law Review, vol. 71, n ${ }^{\circ} 4$ (1988), pp. 703 - 747.

STEIN, Ulrich, "Acerca del concepto de declaración falsa", Trad.: KISS, Alejandro, Revista electrónica de ciencia penal y criminología, vol. 10, nº 15 (2008) pp. 1 26

TORÍO LÓPEZ, Ángel, "Introducción al falso testimonio", Revista de Derecho Procesal, $\mathrm{n}^{\circ} 1$ (1965), pp. $1-25$.

VIERA MORENTE, Francisco J., "El falso testimonio, cambios introducidos por el Código Penal de 1995 e influencia de la Ley del Tribunal del Jurado", en: CADENAS CORTINA, Cristina (Dir.), et al, Delitos contra la administración de justicia, Madrid: Cuadernos de Derecho Judicial, Escuela Judicial, Consejo General del Poder Judicial, 1997.

WALD, Patricia M., "Dealing with witnesses in War Crime Trials: Lessons form the yugoslav Tribunal" Yale Human Rights and Development Law Journal, vol. 5 (2002), pp. $217-239$.

WHITMAN, Alfred David, "A proposed solution to the problem of perjury in our courts", Dickinson Law Review, vol. 57 (1954), pp. 127 - 149.

WILENMANN VON BERNATH, Javier, "El concepto de falsedad en el falso testimonio, una introducción a la dogmática general de los delitos de falsedad", Revista Chilena de Derecho, vol. 41, ${ }^{\circ} 1$ (2014), pp. 59 - 88.

ZAHAR, Alexander, "The problem of false testimony at the International Criminal Tribunal for Rwanda", en: KLIP, André; GÖRAN, Sluiter (Eds), Annotated leading cases of international criminal tribunals, Vol. 25: International Criminal Tribunal for Rwanda, 2006-2007, Intersentia, 2010. 